\title{
Article \\ Screening for Selective Anticancer Activity of 65 Extracts of Plants Collected in Western Andalusia, Spain
}

\author{
José Manuel Calderón-Montaño ${ }^{1, *(1)}$, Sara María Martínez-Sánchez ${ }^{2,3}\left({ }^{1}\right.$, Víctor Jiménez-González ${ }^{1}$, \\ Estefanía Burgos-Morón ${ }^{1}$, Emilio Guillén-Mancina ${ }^{1}$, Julio José Jiménez-Alonso ${ }^{1}$, Patricia Díaz-Ortega ${ }^{1}$, \\ Felipe García ${ }^{2}$, Abelardo Aparicio ${ }^{2}$ and Miguel López-Lázaro ${ }^{1, *[1}$
}

1 Department of Pharmacology, Faculty of Pharmacy, University of Seville, 41012 Seville, Spain; vjimenez3@us.es (V.J.-G.); eburgos1@us.es (E.B.-M.); eguillen@us.es (E.G.-M.); juljimalo@alum.us.es (J.J.J.-A.); patdiaort@alum.us.es (P.D.-O.)

2 Department of Vegetal Biology and Ecology, Faculty of Pharmacy, University of Seville, 41012 Seville, Spain; smmartinez2@ucam.edu (S.M.M.-S.); fgm@us.es (F.G.); abelardo@us.es (A.A.)

3 Department of Food Technology and Nutrition, San Antonio Catholic University, 30107 Murcia, Spain

* Correspondence: jcalderon@us.es (J.M.C.-M.); mlopezlazaro@us.es (M.L.-L.); Tel.: +34-954-55-63-48 (M.L.-L.)

Citation: Calderón-Montaño, J.M.; Martínez-Sánchez, S.M.;

Jiménez-González, V.; Burgos-Morón, E.; Guillén-Mancina, E.; Jiménez-Alonso, J.J.; Díaz-Ortega, P.; García, F.; Aparicio, A.; López-Lázaro, M. Screening for Selective Anticancer Activity of 65 Extracts of Plants Collected in Western Andalusia, Spain. Plants 2021, 10, 2193. https:// doi.org/10.3390/plants10102193

Academic Editors:

Rodica-Mihaela Dinică and Bianca Furdui

Received: 17 September 2021 Accepted: 12 October 2021 Published: 15 October 2021

Publisher's Note: MDPI stays neutral with regard to jurisdictional claims in published maps and institutional affiliations.

Copyright: (c) 2021 by the authors. Licensee MDPI, Basel, Switzerland. This article is an open access article distributed under the terms and conditions of the Creative Commons Attribution (CC BY) license (https:// creativecommons.org/licenses/by/ $4.0 /)$.

\begin{abstract}
Finding cytotoxic drugs with a high selectivity towards cancer cells is crucial to improve the low survival rates of patients diagnosed with metastatic cancers. Since plants are an important source of anticancer drugs, we have screened 65 extracts from 45 plants collected in several areas of Western Andalusia (Spain) for cytotoxic activity on lung cancer cells versus lung normal cells. An extract from the leaves of Tetraclinis articulata (Vahl) Mast. (Cupressaceae) showed a marked cytotoxicity ( $\mathrm{IC} 50=0.37 \pm 0.03 \mu \mathrm{g} / \mathrm{mL}$ ) and selectivity (selectivity index $=378.3$ ) against the lung cancer cells; cisplatin, 5-fluorouracil, and an extract from the leaves of Taxus baccata L. (Taxaceae) were less cytotoxic and selective. Extracts from Cascabela thevetia (L.) Lippold (Apocynaceae), Frangula alnus Mill. (Rhamnaceae), Iberis ciliata subsp. contracta (Pers.) Moreno (Brassicaceae), Juniperus macrocarpa Sm (Cupressaceae), and Pancratium maritimum L. (Amaryllidaceae) also showed selective cytotoxicity (selectivity index $>10$ ). Active extracts were also tested against a panel of cancer cell lines from a variety tissues. The plants identified in this work are potential sources of natural compounds with selective toxicity towards cancer cells.
\end{abstract}

Keywords: cancer; lung cancer; selectivity; Tetraclinis articulata (Vahl) Mast.; Cupressaceae

\section{Introduction}

Despite the recent approval of new anticancer treatments, metastasis continues to be an incurable disease for most cancer patients. The limited efficacy of the existing therapies is reflected in the poor survival rates of patients diagnosed with the most common metastatic cancers [1]. For example, distant metastases occur in $57 \%$ of patients diagnosed with lung cancer, and only $6 \%$ of them survive 5 years after diagnosis [1]. The percentages are also low for other common metastatic cancers. The five-year relative survival rates for patients with distant metastases are $30 \%$ in prostate cancer, $28 \%$ in breast cancer, $14 \%$ in colorectal cancer, $27 \%$ in melanoma, $13 \%$ in renal cancer, $30 \%$ in ovarian cancer, $17 \%$ in cancers of the uterine corpus, $17 \%$ in cancers of the uterine cervix, $6 \%$ in bladder cancer, $5 \%$ in esophageal cancer, $3 \%$ in liver cancer, and 3\% in pancreatic cancer [1]. Many patients with metastases do not overcome the disease despite surviving five years after diagnosis.

Understanding why the current treatments rarely cure patients with disseminated disease is important to discover better therapies. When one treats cancer cells with specific concentrations of the available anticancer drugs and examines the cells under the microscope, one generally observes a massacre. All cancer cells die in response to most treatments. However, these drugs also kill normal cells at similar concentrations. The consequence of this limited selectivity is that patients cannot receive the drug doses needed 
to kill all their cancer cells; such doses would also kill their normal body cells and would be lethal. Although oncology patients generally receive the maximum tolerated doses, these doses are usually insufficient to reach the drug concentrations required to eradicate their cancer cells. The surviving cancer cells continue to proliferate and eventually lead to a fatal outcome. Finding drugs with a high selectivity towards cancer cells is crucial to develop more effective treatments for patients with metastasis [2-4].

Several plants have provided useful drugs for the treatment of a variety of cancers, including lung cancer [5-7]. For example, the diterpene paclitaxel (isolated from the bark of Taxus brevifolia Nutt., Taxaceae) and its semisynthetic derivative docetaxel are FDA-approved drugs for the treatment of non-small-cell lung cancer [8,9]. Vinorelbine, a semisynthetic analog of the vinca alkaloids (isolated from Catharanthus roseus G. Don., Apocynaceae), is also approved for patients with this type of cancer [9]. Etoposide (a semi-synthetic analogue of the natural lignan podophyllotoxin, isolated from Podophyllum species, Podophyllaceae) and topotecan (an analogue of the quinoline alkaloid camptotethin, isolated from Camptotheca acuminata Decne, Nyssaceae) are approved for patients with small cell lung cancer. Due to the fact that several plants have provided useful anticancer agents, we recently used lung cancer cells and lung normal cells to evaluate the selective anticancer activity of 57 extracts from plants collected in Grazalema Natural Park (Andalusia, Spain) [10]. Using a similar experimental approach, we have evaluated the selective anticancer activity of 65 extracts from 45 new plants collected in several areas of Western Andalusia, and report the results in this article.

\section{Results and Discussion}

Due to the fact that patients with metastatic cancers need selective anticancer drugs, we have searched for potential sources of selective anticancer drugs in 45 plants growing in Western Andalusia, Spain. After collecting the plant material and preparing 65 extracts, we used lung cancer cells (A549) and lung normal cells (MRC-5) to evaluate their selective cytotoxicity with the MTT assay. A549 cells are epithelial cells and MRC- 5 cells are fibroblastic cells. However, since normal epithelial cells are difficult to maintain and expand in culture, we selected this widely used normal cell line for our screening [11-13].

We exposed both cell lines for $72 \mathrm{~h}$ to at least five concentrations of the extracts and the anticancer drugs cisplatin and 5-fluorouracil (5-FU). Table 1 shows the botanical names in alphabetical order, the plant families and other pertinent information on the 45 plant species. It also shows an identification number for each extract, the IC50 value for each cell line, and the selectivity index. Dose-response curves for the 65 extracts and positive controls are provided in Figures 1-6; these curves allow for the visualization of their cytotoxic profile over a wide concentration range. 
Table 1. Cytotoxic activity of plant extracts on lung cancer cells (A549) versus lung normal cells (MRC-5).

\begin{tabular}{|c|c|c|c|c|c|c|c|}
\hline \multirow[t]{2}{*}{ Extract } & \multirow[t]{2}{*}{ Plant Name (Family) } & \multirow[t]{2}{*}{ Part Used } & \multirow[t]{2}{*}{$\begin{array}{c}\text { Voucher Number } \\
\text { (SEV) }\end{array}$} & \multirow[t]{2}{*}{ Origin } & \multicolumn{2}{|c|}{$\begin{array}{c}\text { IC50 (MTT) } \\
(\text { Mean } \pm \text { SEM, } \mu \mathrm{g} / \mathrm{mL})\end{array}$} & \multirow[t]{2}{*}{$\begin{array}{c}\text { S.I. } \\
\text { (Mean } \pm \text { SEM) }\end{array}$} \\
\hline & & & & & A549 (Cancer) & MRC-5 (Normal) & \\
\hline 1 & Acis autumnalis (L.) Sweet (Amaryllidaceae) & Whole plant & 284654 & Seville & $32.9 \pm 9.6$ & $59.1 \pm 18.0$ & $1.9 \pm 0.6$ \\
\hline 2 & Anagallis monelli L. (Primulaceae) & Aerial Parts & 284675 & Cádiz & $3.2 \pm 1.4$ & $0.6 \pm 0.2$ & $0.3 \pm 0.2$ \\
\hline 3 & Anagallis monelli L. (Primulaceae) & Root & 284675 & Cádiz & $7.4 \pm 5.2$ & $0.9 \pm 0.5$ & $0.3 \pm 0.3$ \\
\hline 4 & Anthyllis hamosa Desf. (Leguminosae) & Whole plant & 284685 & Huelva & $260.9 \pm 14.7$ & $317.7 \pm 3.1$ & $1.2 \pm 0.1$ \\
\hline 5 & Aristolochia baetica L. (Aristolochiaceae) & Fruits & 284674 & Seville & $249.1 \pm 2.5$ & $649.9 \pm 345.0$ & $2.6 \pm 1.4$ \\
\hline 6 & Aristolochia baetica L. (Aristolochiaceae) & Leaves & 284674 & Seville & $91.8 \pm 70.5$ & $66.0 \pm 39.9$ & $0.9 \pm 0.3$ \\
\hline 7 & $\begin{array}{c}\text { Armeria pungens (Link) Hoffmanns. \& Link } \\
\text { (Plumbaginaceae) }\end{array}$ & $\begin{array}{l}\text { Flowering aerial } \\
\text { parts }\end{array}$ & 284687 & Huelva & $143.4 \pm 64.3$ & $550.7 \pm 352.2$ & $3.6 \pm 1.1$ \\
\hline 8 & $\begin{array}{c}\text { Armeria velutina Welw. ex Boiss. \& Reut. } \\
\text { (Plumbaginaceae) }\end{array}$ & Whole plant & 284689 & Huelva & $25.7 \pm 1.9$ & $36.7 \pm 0.9$ & $1.4 \pm 0.1$ \\
\hline 9 & Campanula lusitanica L. (Campanulaceae) & Whole plant & 284667 & Seville & $223.4 \pm 51.2$ & $263.7 \pm 34.2$ & $1.3 \pm 0.4$ \\
\hline 10 & $\begin{array}{c}\text { Cascabela thevetia (L.) Lippold } \\
\text { (Apocynaceae) }\end{array}$ & Leaves & 284662 & Seville & $0.14 \pm 0.02$ & $1.6 \pm 0.5$ & $26.6 \pm 11.6$ \\
\hline 11 & Centaurea sphaerocephala L. (Compositae) & Whole plant & 284683 & Huelva & $134.2 \pm 82.4$ & $160.4 \pm 33.8$ & $1.7 \pm 0.8$ \\
\hline 12 & Centaurea sphaerocephala L. (Compositae) & Flowers & 284676 & Cádiz & $139.1 \pm 40.1$ & $108.7 \pm 7.7$ & $1.7 \pm 1.1$ \\
\hline 13 & Centaurea sphaerocephala L. (Compositae) & Leaves & 284676 & Cádiz & $43.1 \pm 11.1$ & $114.7 \pm 14.4$ & $3.0 \pm 0.8$ \\
\hline 15 & Cistus crispus L. (Cistaceae) & Root & 284660 & Seville & $24.9 \pm 0.7$ & $58.8 \pm 14.8$ & $2.1 \pm 0.7$ \\
\hline 16 & Cistus salviifolius L. (Cistaceae) & Leaves & 284653 & Seville & $56.6 \pm 12.6$ & $142.7 \pm 20.4$ & $3.0 \pm 0.9$ \\
\hline 17 & Cleome violacea L. (Cleomaceae) & Aerial Parts & 284668 & Seville & $253.9 \pm 39.9$ & $261.1 \pm 3.4$ & $1.1 \pm 0.2$ \\
\hline 18 & Digitalis purpurea L. (Plantaginaceae) & Leaves & 284691 & Huelva & $0.17 \pm 0.15$ & $1.06 \pm 0.69$ & $9.3 \pm 0.5$ \\
\hline 19 & Dorycnium rectum (L.) Ser. (Leguminosae) & Flowers & 284690 & Seville & $102.1 \pm 40.2$ & $182.9 \pm 46.1$ & $4.3 \pm 3.2$ \\
\hline 20 & Dorycnium rectum (L.) Ser. (Leguminosae) & Leaves & 284690 & Seville & $293.6 \pm 21.2$ & $322.1 \pm 27.4$ & $1.1 \pm 0.2$ \\
\hline 21 & Echium gaditanum Boiss. (Boraginaceae) & Aerial Parts & 284684 & Huelva & $196.1 \pm 107.2$ & $325.6 \pm 44.0$ & $1.1 \pm 0.1$ \\
\hline 22 & Elaeoselinum foetidum (L.) Boiss. (Apiaceae) & Flowers & 284670 & Seville & $119.0 \pm 16.2$ & $262.1 \pm 8.7$ & $2.3 \pm 0.3$ \\
\hline 23 & Elaeoselinum foetidum (L.) Boiss. (Apiaceae) & Leaves & 284670 & Seville & $246.5 \pm 25.5$ & $295.0 \pm 36.4$ & $1.2 \pm 0.0$ \\
\hline 24 & Erica arborea L. (Ericaceae) & Bark & 284657 & Seville & $32.2 \pm 5.6$ & $62.1 \pm 28.9$ & $1.8 \pm 0.7$ \\
\hline 25 & Erica arborea L. (Ericaceae) & Leaves & 284657 & Seville & $45.7 \pm 7.4$ & $158.4 \pm 43.6$ & $3.9 \pm 1.4$ \\
\hline 26 & Erophaca baetica (L.) Boiss. (Leguminosae) & Leaves & 284673 & Seville & $>1000$ & $>1000$ & N.D. \\
\hline 27 & Frangula alnus Mill. (Rhamnaceae) & Bark & 284680 & Huelva & $32.8 \pm 7.4$ & $339.3 \pm 74.1$ & $12.4 \pm 3.3$ \\
\hline 28 & Frangula alnus Mill. (Rhamnaceae) & Leaves & 284680 & Huelva & $28.6 \pm 3.5$ & $74.0 \pm 38.5$ & $2.4 \pm 1.0$ \\
\hline 29 & Genista hirsuta M.Vahl (Leguminosae) & Aereal Parts & 284671 & Seville & $273.6 \pm 5.8$ & $363.9 \pm 27.9$ & $1.3 \pm 0.1$ \\
\hline 30 & Halimium calycinum (L.) K.Koch (Cistaceae) & Leaves & 284656 & Seville & $47.4 \pm 10.0$ & $135.4 \pm 23.6$ & $4.3 \pm 1.9$ \\
\hline
\end{tabular}


Table 1. Cont.

\begin{tabular}{|c|c|c|c|c|c|c|c|}
\hline \multirow[t]{2}{*}{ Extract } & \multirow[t]{2}{*}{ Plant Name (Family) } & \multirow[t]{2}{*}{ Part Used } & \multirow[t]{2}{*}{$\begin{array}{l}\text { Voucher Number } \\
\text { (SEV) }\end{array}$} & \multirow[t]{2}{*}{ Origin } & \multicolumn{2}{|c|}{$\begin{array}{c}\text { IC50 (MTT) } \\
(\text { Mean } \pm \text { SEM, } \mu \mathrm{g} / \mathrm{mL})\end{array}$} & \multirow[t]{2}{*}{$\begin{array}{c}\text { S.I. } \\
(\text { Mean } \pm \text { SEM) }\end{array}$} \\
\hline & & & & & A549 (Cancer) & MRC-5 (Normal) & \\
\hline 31 & Halimium calycinum (L.) K.Koch (Cistaceae) & Root & 284656 & Seville & $60.1 \pm 17.7$ & $101.1 \pm 13.6$ & $2.2 \pm 0.8$ \\
\hline 32 & Halimium halimifolium (L.) Willk. (Cistaceae) & Leaves & 284659 & Seville & $47.9 \pm 10.9$ & $105.9 \pm 21.4$ & $2.7 \pm 0.9$ \\
\hline 33 & Halimium halimifolium (L.) Willk. (Cistaceae) & Root & 284659 & Seville & $67.5 \pm 16.0$ & $110.2 \pm 33.4$ & $1.8 \pm 0.8$ \\
\hline 34 & Hedysarum coronarium L. (Leguminosae) & Flowers & 284677 & Cádiz & $230.5 \pm 54.6$ & $306.9 \pm 55.1$ & $1.4 \pm 0.1$ \\
\hline 35 & Hedysarum coronarium L. (Leguminosae) & Fruits & 284677 & Cádiz & $247.0 \pm 3.2$ & $294.5 \pm 0.4$ & $1.2 \pm 0.0$ \\
\hline 36 & Hedysarum coronarium L. (Leguminosae) & Leaves & 284677 & Cádiz & $173.9 \pm 60.6$ & $262.0 \pm 32.3$ & $2.1 \pm 0.9$ \\
\hline 37 & $\begin{array}{c}\text { Iberis ciliata subsp. contracta (Pers.) Moreno } \\
\text { (Brassicaceae) }\end{array}$ & Whole plant & 284688 & Huelva & $0.31 \pm 0.06$ & $2.31 \pm 0.88$ & $13.0 \pm 4.7$ \\
\hline 38 & Jasione montana L. (Campanulaceae) & Whole plant & 284666 & Seville & $145.0 \pm 26.0$ & $301.6 \pm 69.2$ & $2.0 \pm 0.1$ \\
\hline 39 & Juniperus macrocarpa Sm. (Cupressaceae) & Monosperma cones & 284682 & Huelva & $146.1 \pm 125.9$ & $>1000$ & $>20$ \\
\hline 40 & Juniperus macrocarpa Sm. (Cupressaceae) & Aerial Parts & 284682 & Huelva & $3.7 \pm 1.9$ & $2.8 \pm 1.0$ & $0.8 \pm 0.1$ \\
\hline 41 & Malcolmia lacera (L.) DC. (Brassicaceae) & Whole plant & 284664 & Seville & $322.3 \pm 86.7$ & $295.0 \pm 5.9$ & $1.0 \pm 0.3$ \\
\hline 42 & Malva hispanica L. (Malvaceae) & Aerial Parts & 284669 & Seville & $>1000$ & $703.1 \pm 51.1$ & N.D. \\
\hline 43 & Ononis subspicata Lag. (Leguminosae) & Whole plant & 284695 & Huelva & $63.9 \pm 23.6$ & $232.3 \pm 29.5$ & $4.6 \pm 1.4$ \\
\hline 44 & Ornithopus compressus L. (Leguminosae) & Whole plant & 284693 & Seville & $340.7 \pm 28.4$ & $583.8 \pm 150.0$ & $1.8 \pm 0.6$ \\
\hline 45 & Ornithopus sativus Brot. (Leguminosae) & Whole plant & 284692 & Seville & $326.6 \pm 37.5$ & $699.0 \pm 262.9$ & $2.3 \pm 1.1$ \\
\hline 47 & $\begin{array}{c}\text { Pycnocomon rutifolium (Vahl) Hoffmanns. \& } \\
\text { Link (Caprifoliaceae) }\end{array}$ & Leaves & 284678 & Cádiz & $71.4 \pm 40.4$ & $70.6 \pm 18.1$ & $2.2 \pm 1.4$ \\
\hline 48 & $\begin{array}{c}\text { Pycnocomon rutifolium (Vahl) Hoffmanns. \& } \\
\text { Link (Caprifoliaceae) }\end{array}$ & Root & 284678 & Cádiz & $262.5 \pm 131,9$ & $242.9 \pm 56.7$ & $1.1 \pm 0.3$ \\
\hline 49 & $\begin{array}{c}\text { Ranunculus peltatus Schrank } \\
\text { (Ranunculaceae) }\end{array}$ & Whole plant & 284672 & Seville & $186.7 \pm 54.6$ & $170.1 \pm 58.8$ & $0.9 \pm 0.1$ \\
\hline 50 & $\begin{array}{l}\text { Rhamnus lycioides subsp. oleoides (L.) Jahand. } \\
\text { \& Maire (Rhamnaceae) }\end{array}$ & Bark & 284655 & Seville & $332.2 \pm 61.9$ & $599.4 \pm 122.1$ & $2.1 \pm 0.8$ \\
\hline 51 & $\begin{array}{c}\text { Rhamnus lycioides subsp. oleoides (L.) Jahand. } \\
\text { \& Maire (Rhamnaceae) }\end{array}$ & Leaves & 284655 & Seville & $151.5 \pm 16.7$ & $421.3 \pm 176.5$ & $3.1 \pm 1.6$ \\
\hline 52 & $\begin{array}{l}\text { Rhamnus lycioides subsp. oleoides (L.) Jahand. } \\
\text { \& Maire (Rhamnaceae) }\end{array}$ & Root & 284655 & Seville & $257.0 \pm 76.6$ & $442.3 \pm 35.1$ & $2.3 \pm 0.8$ \\
\hline 53 & Scrophularia frutescens L. (Scrophulariaceae) & Whole plant & 284686 & Huelva & $281.5 \pm 9.2$ & $297.6 \pm 8.6$ & $1.1 \pm 0.1$ \\
\hline 54 & $\begin{array}{c}\text { Stauracanthus genistoides (Brot.) G. Sampaio } \\
\text { (Leguminosae) }\end{array}$ & Aerial Parts & 284679 & Huelva & $278.4 \pm 32.9$ & $546.5 \pm 53.5$ & $2.0 \pm 0.4$ \\
\hline 55 & Tamarix canariensis Willd. (Tamaricaceae) & Flowers & 284650 & Seville & $212.8 \pm 10.2$ & $336.3 \pm 3.6$ & $1.6 \pm 0.1$ \\
\hline
\end{tabular}


Table 1. Cont.

\begin{tabular}{|c|c|c|c|c|c|c|c|}
\hline \multirow[t]{2}{*}{ Extract } & \multirow[t]{2}{*}{ Plant Name (Family) } & \multirow[t]{2}{*}{ Part Used } & \multirow[t]{2}{*}{$\begin{array}{c}\text { Voucher Number } \\
\text { (SEV) }\end{array}$} & \multirow[t]{2}{*}{ Origin } & \multicolumn{2}{|c|}{$\begin{array}{c}\text { IC50 (MTT) } \\
(\text { Mean } \pm \text { SEM, } \mu \mathrm{g} / \mathrm{mL})\end{array}$} & \multirow[t]{2}{*}{$\begin{array}{c}\text { S.I. } \\
(\text { Mean } \pm \text { SEM) }\end{array}$} \\
\hline & & & & & A549 (Cancer) & MRC-5 (Normal) & \\
\hline 56 & Tamarix canariensis Willd. (Tamaricaceae) & Leaves & 284650 & Seville & $92.7 \pm 24.6$ & $192.1 \pm 33.0$ & $2.2 \pm 0.3$ \\
\hline 57 & Taxus baccata L. (Taxaceae) & Leaves & 284621 & Seville & $0.86 \pm 0.27$ & $146.9 \pm 87.8$ & $157.3 \pm 110.6$ \\
\hline 58 & $\begin{array}{l}\text { Tetraclinis articulata (Vahl) Mast. } \\
\text { (Cupressaceae) }\end{array}$ & Leaves & 284663 & Seville & $0.37 \pm 0.03$ & $129.5 \pm 64.0$ & $378.3 \pm 178.1$ \\
\hline 59 & Teucrium fruticans L. (Lamiaceae) & Leaves & 284658 & Seville & $157.1 \pm 30.5$ & $433.0 \pm 112.3$ & $2.8 \pm 0.7$ \\
\hline 60 & Thymus mastichina (L.) L. (Lamiaceae) & Whole plant & 284694 & Huelva & $36.8 \pm 7.7$ & $277.7 \pm 40.6$ & $8.2 \pm 2.0$ \\
\hline 61 & Tolpis barbata (L.) Gaertn. (Compositae) & Whole plant & 284665 & Seville & $86.5 \pm 28.3$ & $43.7 \pm 12.2$ & $0.5 \pm 0.0$ \\
\hline 62 & $\begin{array}{l}\text { Ulex parviflorus Pourr. subsp. parviflorus } \\
\text { (Leguminosae) }\end{array}$ & Flowers & 284652 & Seville & $361.7 \pm 89.6$ & $876.1 \pm 426.1$ & $4.0 \pm 2.9$ \\
\hline 63 & $\begin{array}{l}\text { Ulex parviflorus Pourr. subsp. parviflorus } \\
\text { (Leguminosae) }\end{array}$ & Leaves & 284652 & Seville & $99.6 \pm 34.8$ & $270.4 \pm 85.3$ & $3.4 \pm 1.2$ \\
\hline 64 & Viburnum tinus L. (Adoxaceae) & Fruits & 284651 & Seville & $26.6 \pm 6.5$ & $65.4 \pm 8.6$ & $2.6 \pm 0.3$ \\
\hline \multirow[t]{3}{*}{65} & Viburnum tinus L. (Adoxaceae) & Leaves & 284651 & Seville & $234.8 \pm 58.7$ & $568.2 \pm 73.0$ & $2.6 \pm 0.3$ \\
\hline & Cisplatin (Standard anticancer drug) & & & & $10.5 \pm 5.5(\mu \mathrm{M})$ & $25.4 \pm 7.4(\mu \mathrm{M})$ & $4.2 \pm 2.2$ \\
\hline & 5-Fluorouracil (Standard anticancer drug) & & & & $\begin{array}{c}101.8 \pm 7.7 \\
(\mu \mathrm{M})\end{array}$ & $\begin{array}{l}>1000 \\
(\mu \mathrm{M})\end{array}$ & $>9.9$ \\
\hline
\end{tabular}

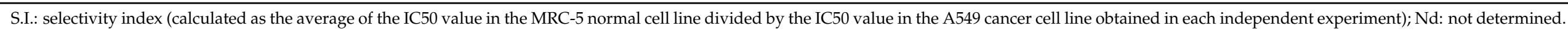



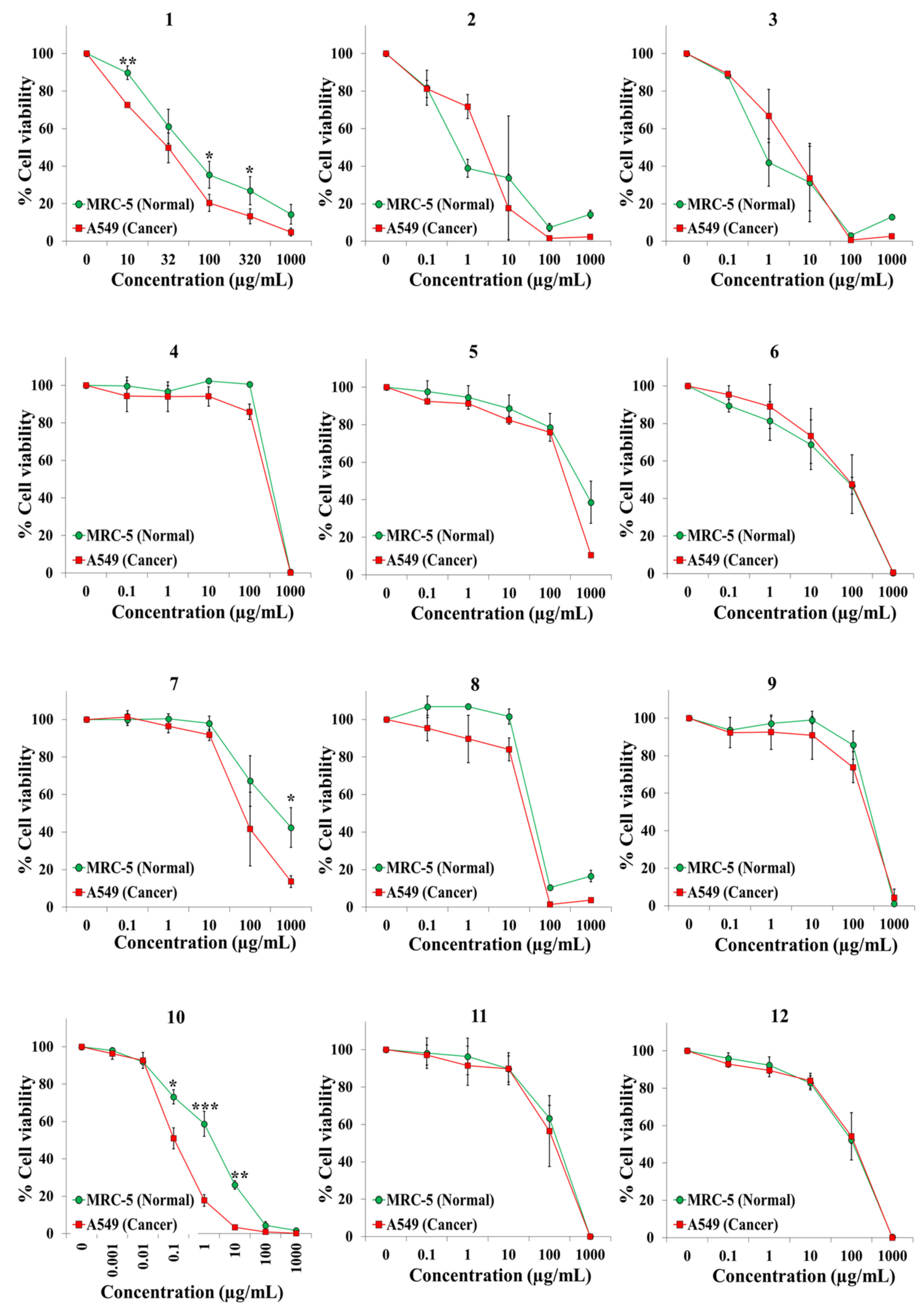

Figure 1. Screening for selective cytotoxic activity of plant extracts 1-12 on A549 lung cancer cells and MRC-5 lung normal cells. The cells were exposed for $72 \mathrm{~h}$ to the extracts and cell viability was determined with the MTT assay. 

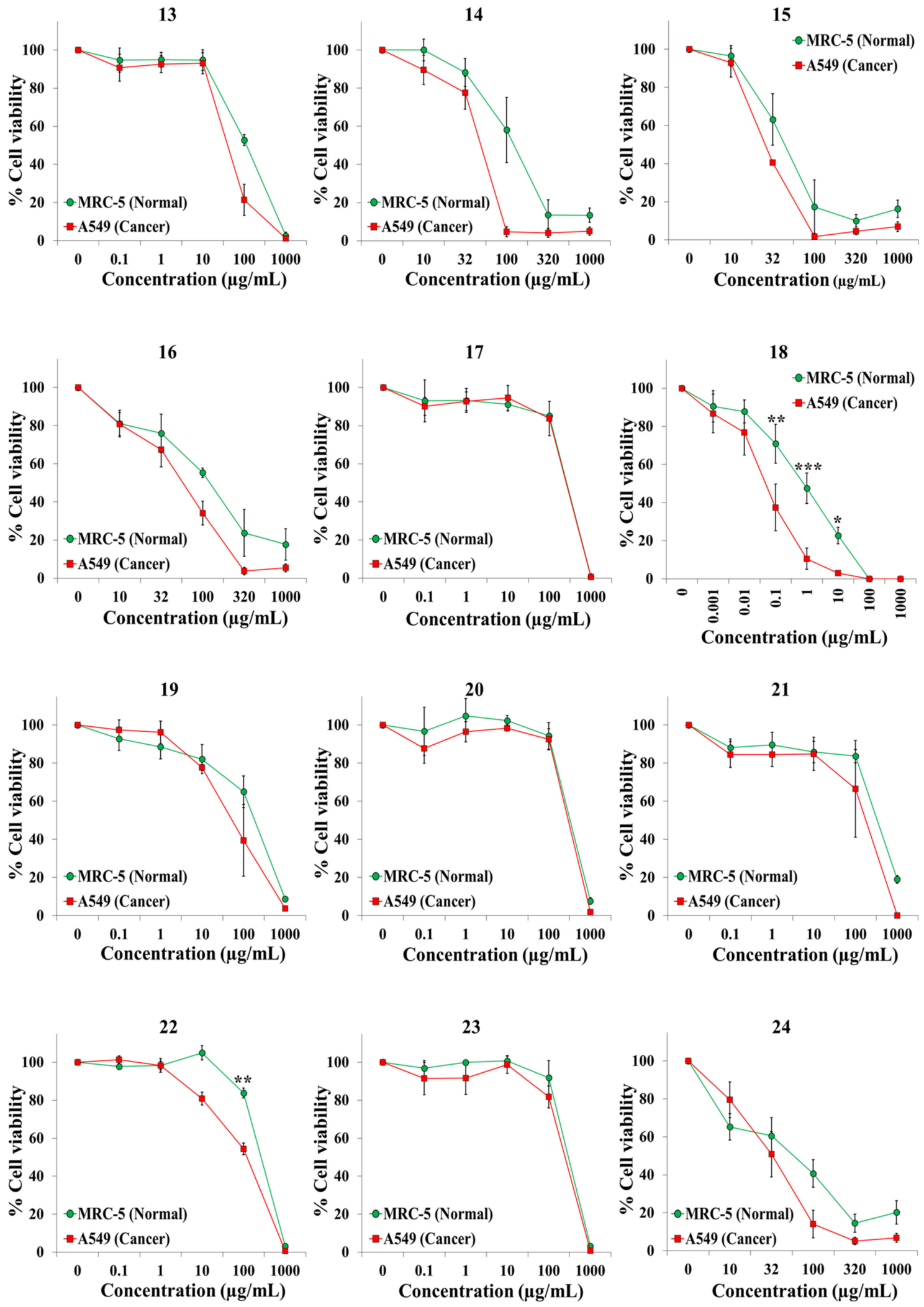

Figure 2. Screening for selective cytotoxic activity of plant extracts 13-24 on A549 lung cancer cells and MRC-5 lung normal cells. The cells were exposed for $72 \mathrm{~h}$ to the extracts and cell viability was determined with the MTT assay. 

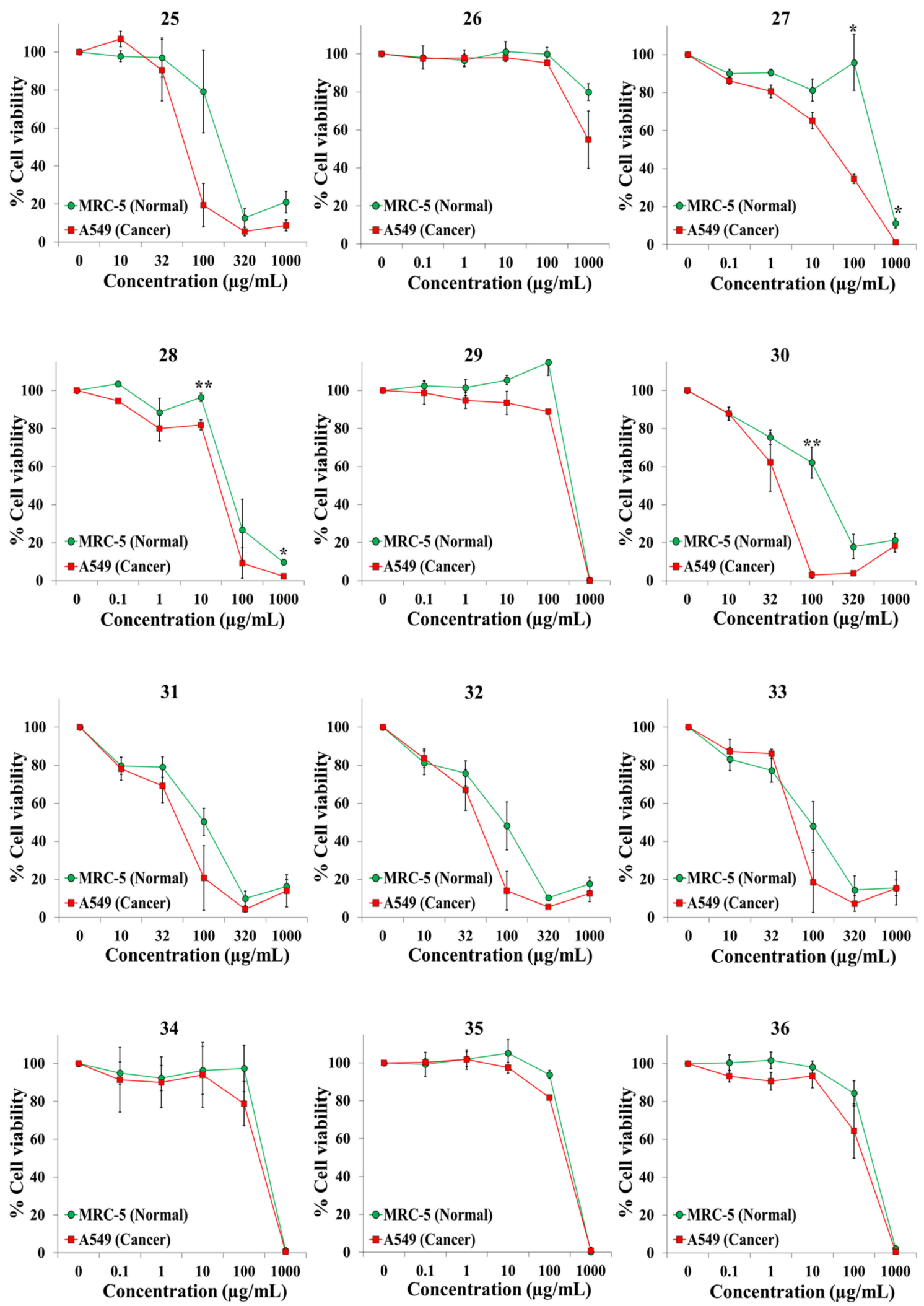

Figure 3. Screening for selective cytotoxic activity of plant extracts 25-36 on A549 lung cancer cells and MRC-5 lung normal cells. The cells were exposed for $72 \mathrm{~h}$ to the extracts and cell viability was determined with the MTT assay. 

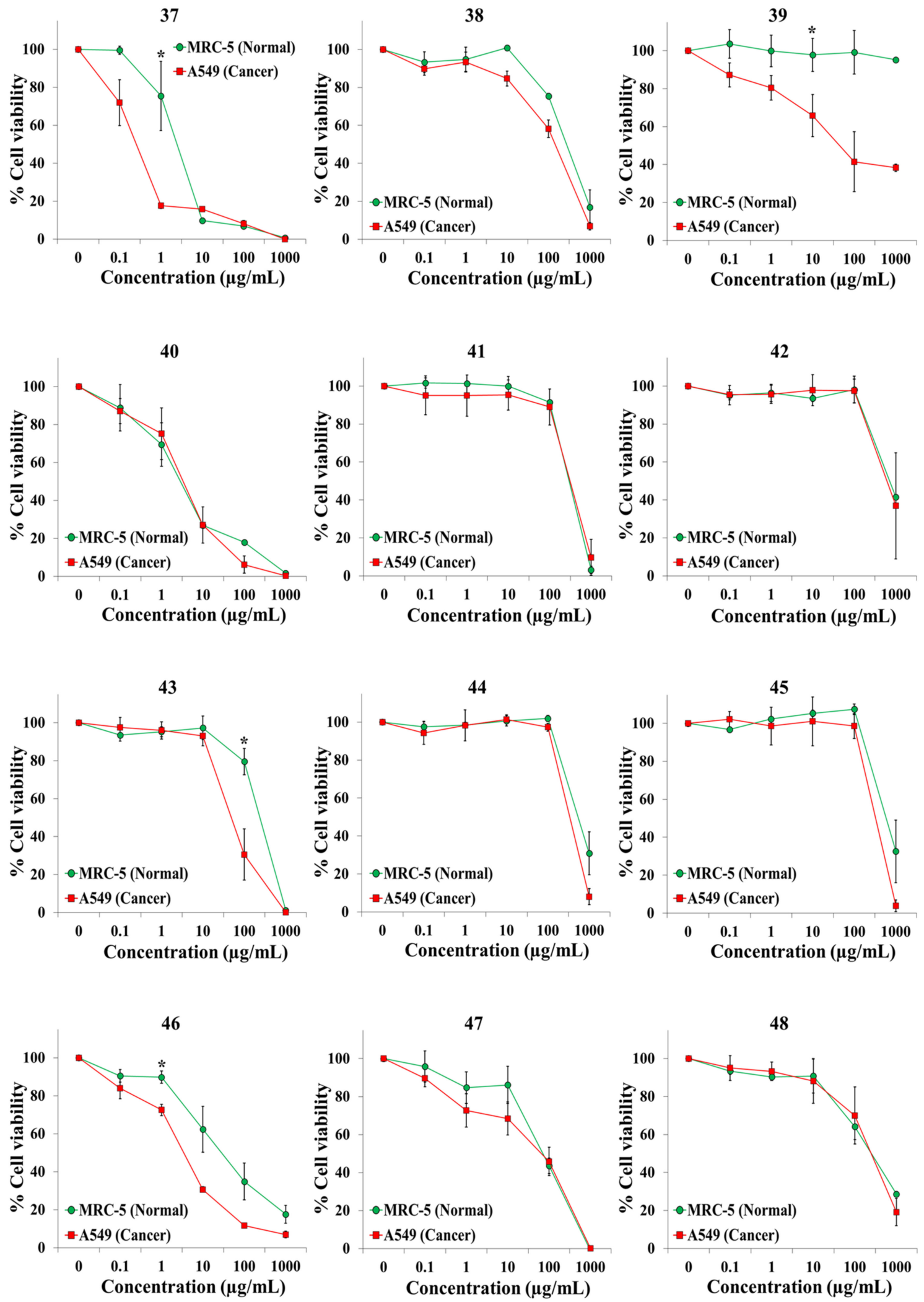

Figure 4. Screening for selective cytotoxic activity of plant extracts 37-48 on A549 lung cancer cells and MRC-5 lung normal cells. The cells were exposed for $72 \mathrm{~h}$ to the extracts and cell viability was determined with the MTT assay. 

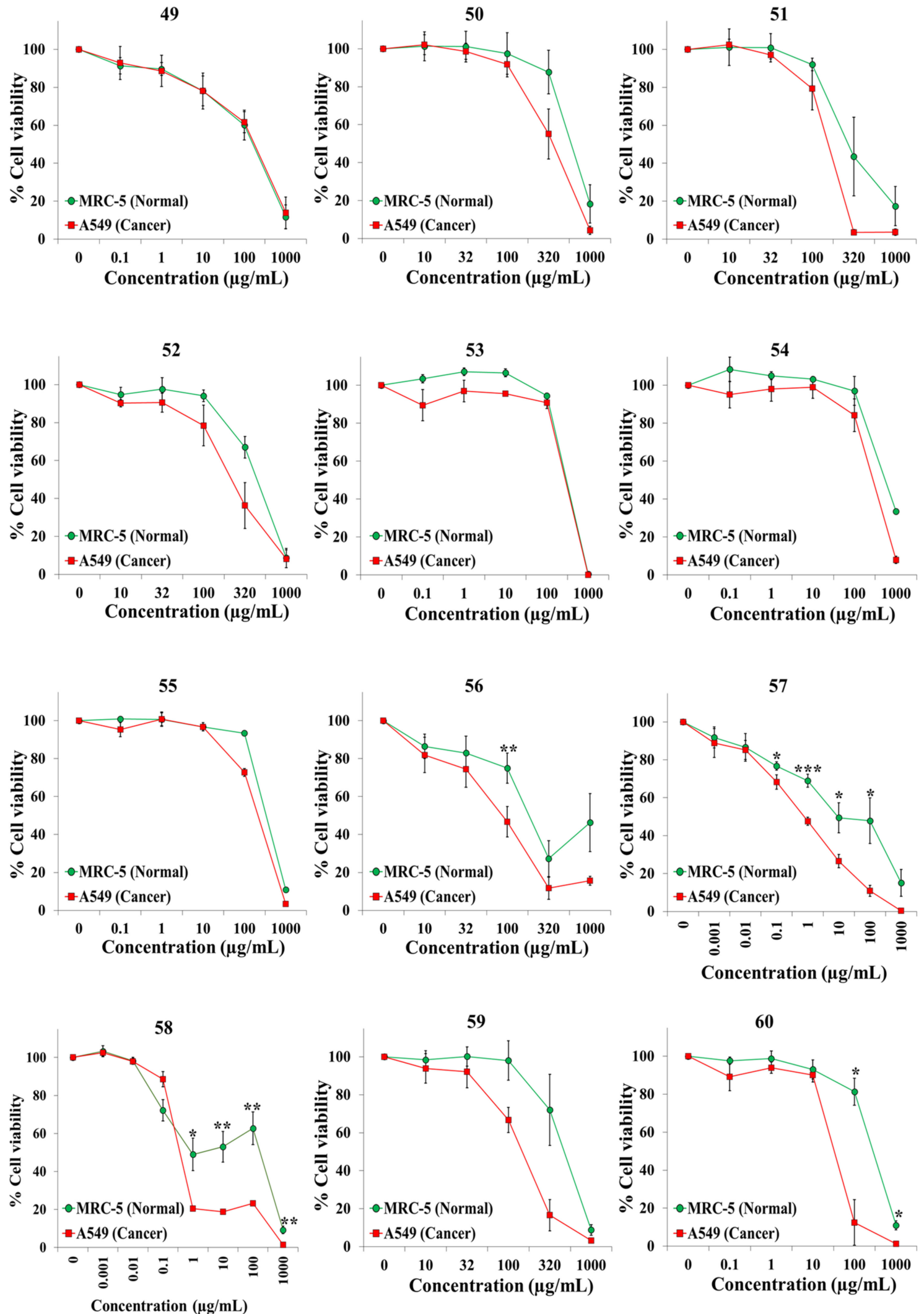

Figure 5. Screening for selective cytotoxic activity of plant extracts 49-60 on A549 lung cancer cells and MRC-5 lung normal cells. The cells were exposed for $72 \mathrm{~h}$ to the extracts and cell viability was determined with the MTT assay. 

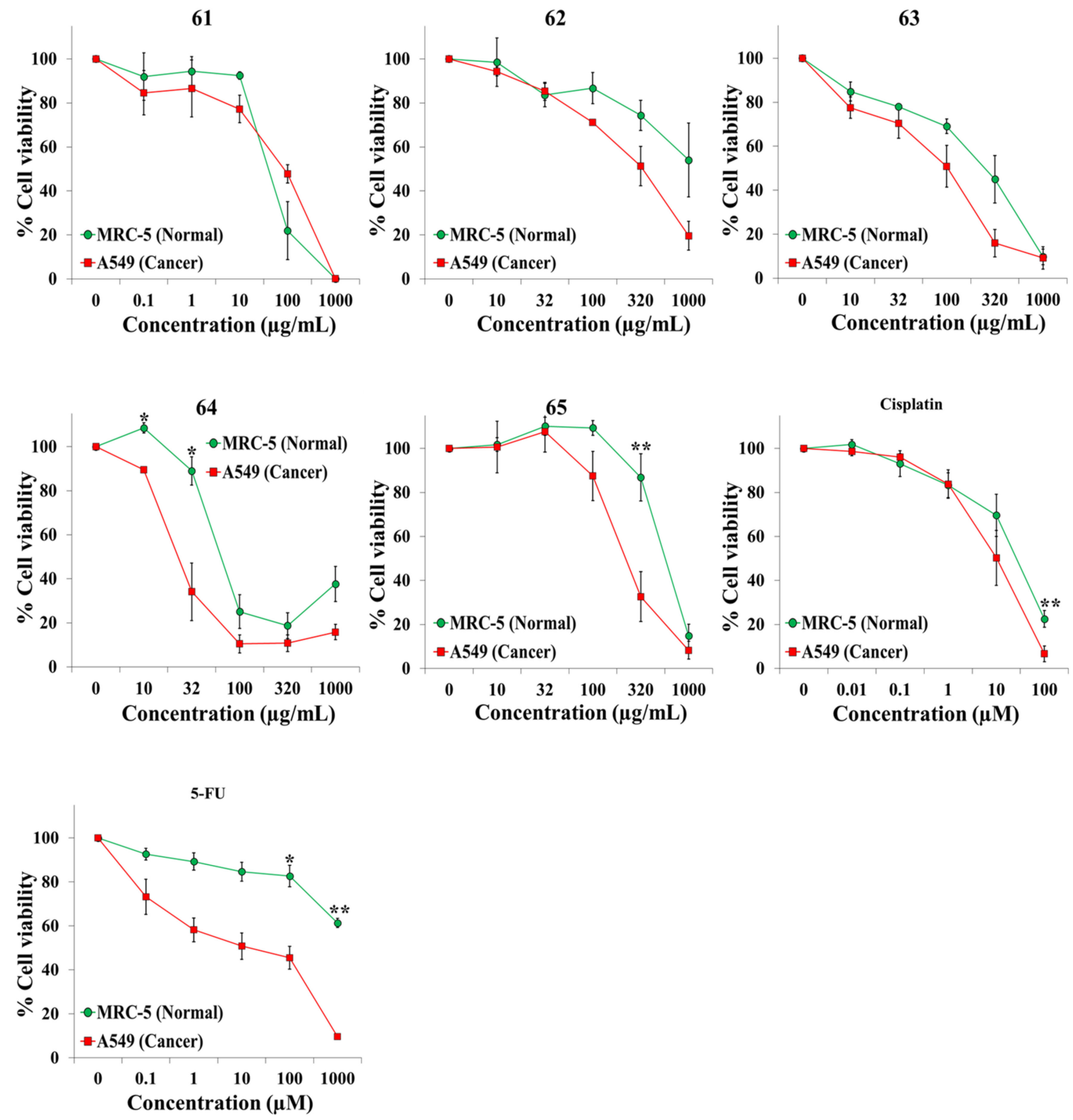

Figure 6. Screening for selective cytotoxic activity of plant extracts 61-65, cisplatin, and 5-fluorouracil (5-FU) on A549 lung cancer cells and MRC-5 lung normal cells. The cells were exposed for $72 \mathrm{~h}$ to the extracts or anticancer drugs and cell viability was determined with the MTT assay.

Results show that several extracts induced selective cytotoxicity towards the cancer cell line, including the extract from the leaves of Cascabela thevetia (L.) Lippold (Apocynaceae) (10), the extract from the leaves of Digitalis purpurea L. (Plantaginaceae) (18), the extract from the bark of Frangula alnus Mill. (Rhamnaceae) (27), the extract from the whole plant Iberis ciliata subsp. contracta (Pers.) Moreno (Brassicaceae) (37), the extract from the seeds of Juniperus macrocarpa Sm. (Cupressaceae) (39), the extract from the bulb of Pancratium maritimum L. (Amaryllidaceae) (46), and the extract from the leaves of Tetraclinis articulata (Vahl) Mast. (Cupressaceae) (58). The anticancer drugs cisplatin and 5-fluorouracil, and an extract from the leaves of Taxus baccata L. (Taxaceae) (57) also showed selectivity against the cancer cells (Table 1). The extract from the leaves of Tetraclinis articulata (Vahl) Mast. (58) (Figure 5) showed the most relevant activ- 
ity; it was more cytotoxic against the lung cancer cells (IC50 $=0.37 \pm 0.03 \mu \mathrm{g} / \mathrm{mL}$ ) than against the lung normal cells (IC50 $=129.5 \pm 64.0 \mu \mathrm{g} / \mathrm{mL}$ ), displaying a selectivity index of $378.3 \pm 178.1$. No significant differences were observed when the cytotoxicity of this extract was tested with the MTT assay and the resazurin assay (Figure S1). Photographs of this plant and the plant material used to prepare the extract are shown in Figure S2. The extract from the leaves of Taxus baccata L. (Taxaceae) was also more cytotoxic against the lung cancer cells (IC50 $=0.86 \pm 0.27 \mu \mathrm{g} / \mathrm{mL}$ ) than against the lung normal cells (IC50 $=146.9 \pm 87.8 \mu \mathrm{g} / \mathrm{mL}$ ), displaying a selectivity index of $157.3 \pm 110.6$. Several extracts (e.g., 4, 6, 9, 11, 12, 17, 20, 23, 34, 35, 41, 42, 48, 49, 53) were cytotoxic but were not selective against the A549 lung cancer cells.

Extracts (10, 18, 37, 46, 57, and 58), and the anticancer drugs cisplatin and 5-fluorouracil, were tested with the resazurin assay against eleven additional cell lines: two leukemia cell lines, six cancer cell lines derived from solid tumors of different tissues (liver, colon, bone, cervix, prostate, and breast), and three genetically modified skin cell lines with increasing degrees of malignancy (Table 2 and Figure 7). Due to the fact that the leukemia cell lines grow in suspension, we determined cell viability with the resazurin assay. Unlike the MTT assay, this assay does not require removal of the culture medium. The extract from the leaves of Tetraclinis articulata (Vahl) Mast. (58) displayed the highest cytotoxic activity, with IC50 values between 0.2 and $2.1 \mu \mathrm{g} / \mathrm{mL}$ against seven of the eight cancer cell lines. No clear differences in cytotoxicity were found for any extract or compound in the three skin cell lines with increasing degrees of malignancy (BJ-hTERT, BJ-SV40T, and BJ-RASV12) [14] (Table 2).

Table 2. Cytotoxicity as IC50 values of selected extracts, cisplatin, and 5-FU on a panel of human cancer cell lines of different tissue origin and three genetically modified skin cell lines. Values are expressed as mean $\pm \mathrm{SEM}$.

\begin{tabular}{|c|c|c|c|c|c|c|c|c|}
\hline \multirow[b]{2}{*}{ Cell Line } & \multicolumn{6}{|c|}{$\begin{array}{c}\text { IC50 (Resazurin) } \\
(\text { Mean } \pm \text { SEM, } \mu \mathrm{g} / \mathrm{mL})\end{array}$} & \multicolumn{2}{|c|}{$\begin{array}{c}\text { IC50 (Resazurin) } \\
\text { (Mean } \pm \text { SEM, } \mu \mathrm{M})\end{array}$} \\
\hline & 10 & 18 & 37 & 46 & 57 & 58 & Cisplatin & 5-FU \\
\hline HepG2 & $24.6 \pm 4.1$ & $13.2 \pm 3.0$ & $19.4 \pm 10.4$ & $7.0 \pm 1.3$ & $632.6 \pm 106.1$ & $18.4 \pm 17.1$ & $3.5 \pm 0.8$ & $0.3 \pm 0.2$ \\
\hline SW480 & $20.7 \pm 5.6$ & $18.3 \pm 1.2$ & $1.2 \pm 0.3$ & $2.1 \pm 0.4$ & $2.2 \pm 0.7$ & $2.1 \pm 0.8$ & $2.0 \pm 0.5$ & $3.4 \pm 1.0$ \\
\hline U2OS & $9.2 \pm 1.5$ & $8.8 \pm 0.8$ & $1.9 \pm 0.2$ & $2.8 \pm 0.7$ & $4.0 \pm 1.2$ & $2.1 \pm 0.9$ & $4.0 \pm 1.0$ & $7.2 \pm 1.0$ \\
\hline HeLa & $4.7 \pm 0.1$ & $4.9 \pm 0.2$ & $3.5 \pm 0.5$ & $5.4 \pm 0.4$ & $2.5 \pm 0.4$ & $1.3 \pm 0.6$ & $4.8 \pm 0.1$ & $66.5 \pm 27.0$ \\
\hline PC3 & $4.7 \pm 1.5$ & $2.6 \pm 0.4$ & $5.6 \pm 2.1$ & $5.4 \pm 1.2$ & $123.8 \pm 42.7$ & $0.50 \pm 0.04$ & $7.3 \pm 4.6$ & $1.5 \pm 0.8$ \\
\hline MCF7 & $10.0 \pm 0.5$ & $6.5 \pm 1.0$ & $4.0 \pm 0.9$ & $5.9 \pm 0.8$ & $37.1 \pm 4.9$ & $0.7 \pm 0.1$ & $8.0 \pm 3.0$ & $1.1 \pm 0.8$ \\
\hline NB4 & $2.9 \pm 0.7$ & $1.8 \pm 0.5$ & $0.5 \pm 0.2$ & $1.2 \pm 0.2$ & $2.8 \pm 0.2$ & $0.2 \pm 0.1$ & $0.08 \pm 0.04$ & $2.7 \pm 0.3$ \\
\hline HL-60 & $3.5 \pm 0.4$ & $3.6 \pm 0.3$ & $0.8 \pm 0.2$ & $1.0 \pm 0.3$ & $3.3 \pm 0.2$ & $0.7 \pm 0.3$ & $0.2 \pm 0.1$ & $0.6 \pm 0.5$ \\
\hline BJ-hTERT & $3.7 \pm 0.4$ & $2.8 \pm 0.3$ & $3.4 \pm 0.5$ & $3.4 \pm 0.1$ & $4.0 \pm 0.6$ & $0.8 \pm 0.3$ & $1.2 \pm 0.4$ & $2.6 \pm 0.6$ \\
\hline BJ-SV40T & $2.9 \pm 0.4$ & $2.1 \pm 0.4$ & $2.9 \pm 0.4$ & $3.2 \pm 0.4$ & $2.8 \pm 0.2$ & $1.0 \pm 0.4$ & $0.7 \pm 0.2$ & $5.8 \pm 0.7$ \\
\hline $\begin{array}{c}\text { BJ- } \\
\text { RASV12 }\end{array}$ & $2.9 \pm 0.4$ & $1.8 \pm 0.7$ & $4.0 \pm 1.4$ & $2.0 \pm 0.7$ & $3.3 \pm 0.2$ & $0.6 \pm 0.2$ & $1.1 \pm 0.1$ & $1.7 \pm 0.8$ \\
\hline
\end{tabular}

HepG2: human hepatocellular carcinoma; SW480: human colon adenocarcinoma; U2OS: human osteosarcoma; HeLa: human cervical carcinoma; PC3: human prostate adenocarcinoma; MCF7: human breast adenocarcinoma; NB4: human acute promyelocytic leukemia; HL-60: human acute promyelocytic leukemia; BJ-hTERT: hTERT-immortalized skin non-malignant BJ; BJ-SV40T: SV40T-transformed BJ-hTERT; BJ-RASV12: H-RAS V12-transformed BJ-SV40T. Extract numbers (10, 18, 37, 46, 57, and 58) can be identified from Table 1.

Due to the fact that Tetraclinis articulata (Vahl) Mast. extract (58) showed a high cytotoxicity against several cancer cell lines, we acquired additional cancer cell lines from a variety of tissues to further evaluate the activity of the extract. Fourteen human cancer cell lines were treated with several concentrations of 58 for $96 \mathrm{~h}$ and cell viability was estimated with the resazurin assay. Results show that this extract was cytotoxic against all the cancer cell lines, with IC50 values in the range $4.3-4.9 \mu \mathrm{g} / \mathrm{mL}$ (Table 3). 


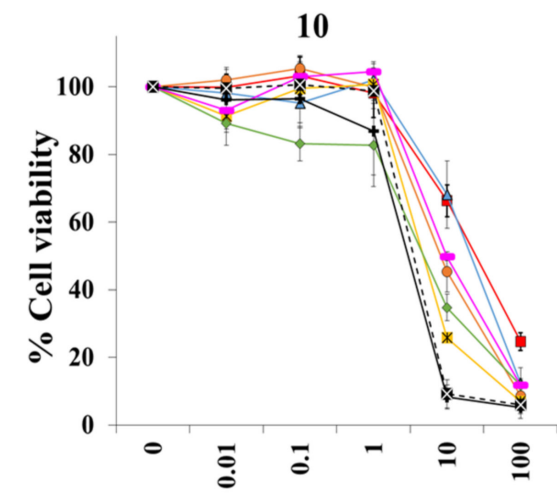

Concentration $(\mu \mathrm{g} / \mathrm{mL})$

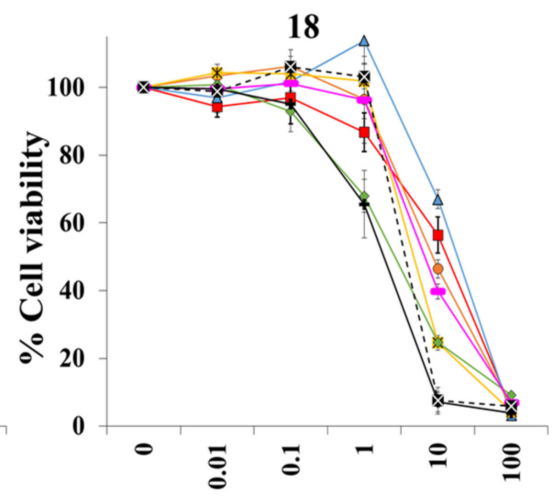

Concentration $(\mu \mathrm{g} / \mathrm{mL})$

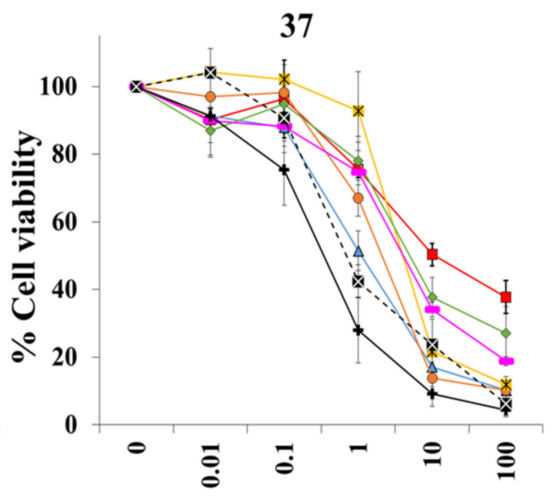

Concentration $(\mu \mathrm{g} / \mathrm{mL})$

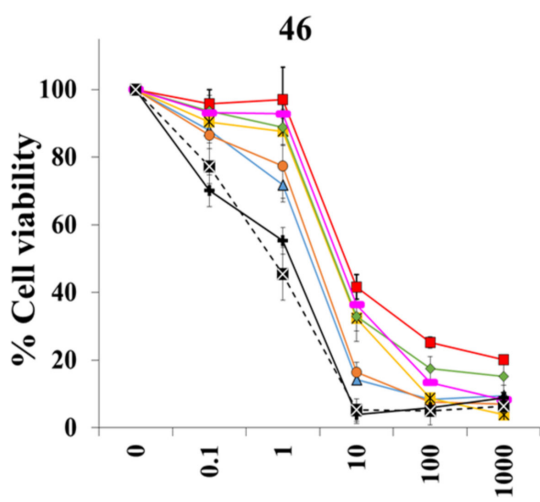

Concentration $(\mu \mathrm{g} / \mathrm{mL})$

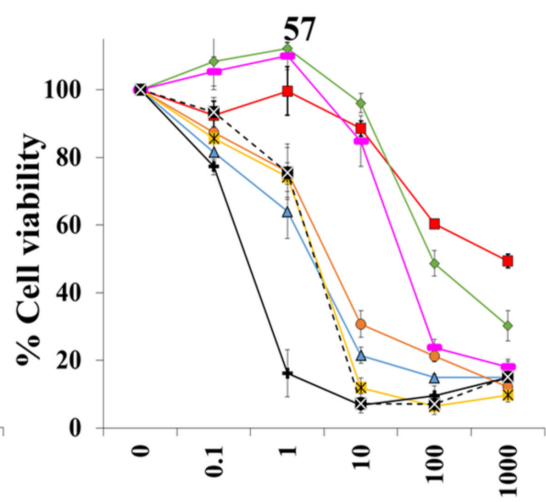

Concentration $(\mu \mathrm{g} / \mathrm{mL})$

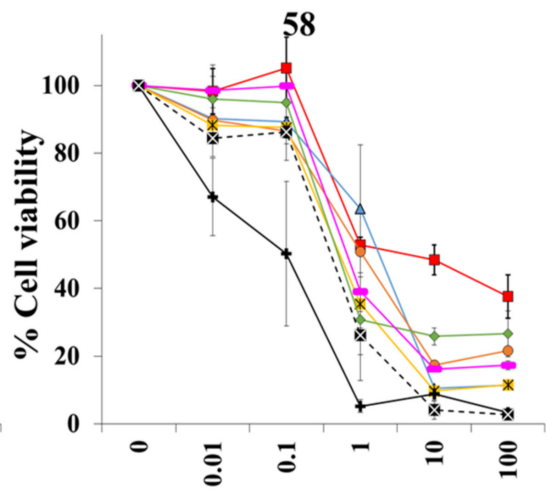

Concentration $(\mu \mathrm{g} / \mathrm{mL})$
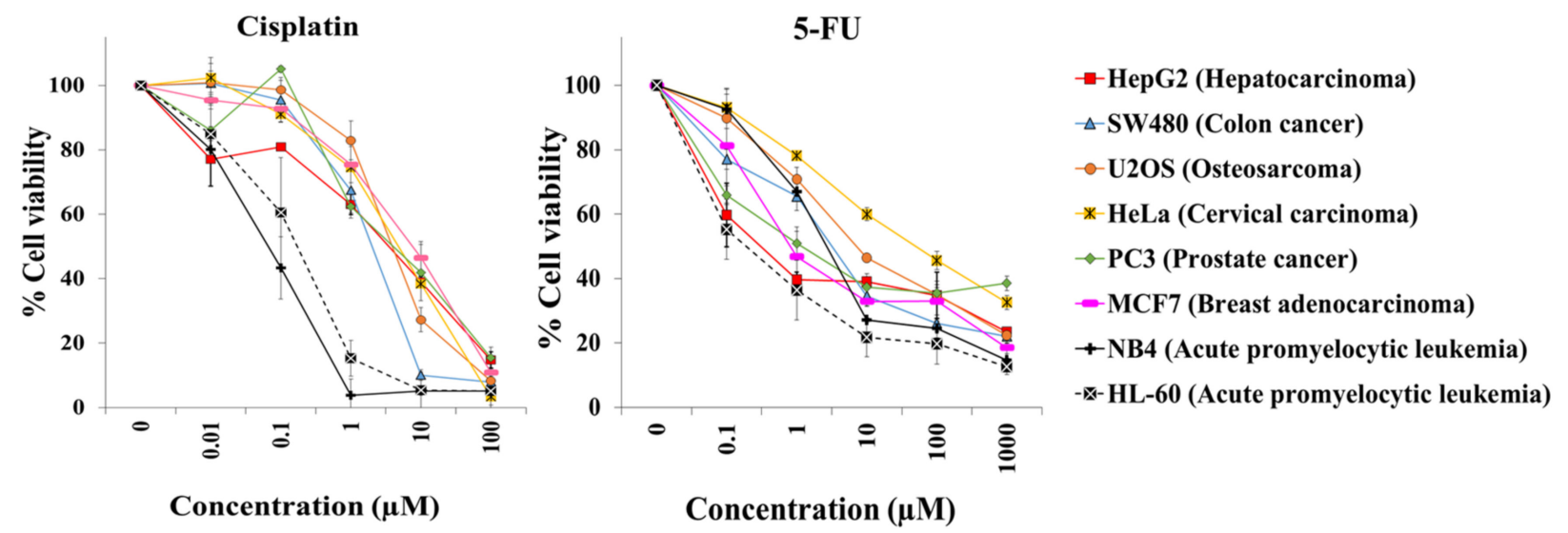

Figure 7. Cytotoxicity of selected plant extracts $(\mathbf{1 0}, \mathbf{1 8}, \mathbf{3 7}, \mathbf{4 6}, \mathbf{5 7}$, and 58), cisplatin, and 5-FU against six cancer cell lines derived from solid tumors and two acute promyelocytic leukemia cell lines. Cells were treated for $72 \mathrm{~h}$, and cell viability was evaluated with the resazurin assay.

Several types of phytochemicals may be involved in the selective anticancer activity shown by the most active extracts. Cardiac glycosides may be responsible for the selective cytotoxicity shown by the extracts from the leaves of Cascabela thevetia (L.) Lippold (10) and the leaves of Digitalis purpurea L. (18). We, and others, have previously observed that plants with cardiac glycosides, and several cardiac glycosides (e.g., digitoxin), induce potent and selective cytotoxic effects against several types of cancer cells, including lung cancer cells [15-23]. Isoquinoline alkaloids may participate in the cytotoxicity and selectivity observed for the extract from the bulb of Pancratium maritimum L. (46) $[24,25]$. The cytotoxicity and selectivity of our extract from the leaves of Taxus baccata L. (57) were probably mediated by different taxane-type diterpenes, including paclitaxel [26,27]. Diterpenes (e.g., 
ferruginol and sandaracopimaric acid.), monoterpenes (e.g., limonene and carveol), and sesquiterpenes (e.g., $\beta$-caryophyllene and humulene) may participate in the cytotoxicity of the extract from the leaves of Tetraclinis articulata (Vahl) Mast. [28-33].

Table 3. Cytotoxic activity of Tetraclinis articulata (Vahl) Mast. (58) against 14 cancer cell lines from a variety of tissues.

\begin{tabular}{cc}
\hline Cell Line & $\begin{array}{c}\text { IC50 (Resazurin) } \\
\text { (Media } \pm \text { SEM, } \boldsymbol{\mu g} / \mathbf{m L})\end{array}$ \\
\hline A64-CLS & $\mathbf{5 8}$ \\
AN3Ca & $4.7 \pm 0.3$ \\
Calu-1 & $4.5 \pm 0.9$ \\
GAMG & $4.7 \pm 0.2$ \\
HNO97 & $4.5 \pm 0.6$ \\
HT29 & $4.5 \pm 0.3$ \\
KATO III & $4.4 \pm 0.4$ \\
MDA-MB-231 & $4.4 \pm 0.7$ \\
MeWo & $4.7 \pm 0.2$ \\
PC-3 & $4.3 \pm 0.2$ \\
Sk-Br-3 & $4.5 \pm 1.0$ \\
Sk-OV-3 & $4.9 \pm 0.0$ \\
T24 & $4.7 \pm 0.1$ \\
UACC-62 & $4.5 \pm 0.3$ \\
\hline
\end{tabular}

A64-CLS: submaxillary gland adenoma; AN3Ca: endometrial adenocarcinoma; Calu-1: squamous lung cancer; GAMG: glioblastoma; HNO97: tongue cancer; HT29: colorectal cancer; KATO III: gastric cancer; MDA-MB-231: triple-negative breast cancer; MeWo: BRAF wild-type melanoma; PC-3: prostate cancer; Sk-Br-3: HER2-positive breast cancer; Sk-OV-3: ovarian cancer; UACC-62: BRAF mutant melanoma; and T24: bladder cancer.

In summary, because patients with advanced cancers need selective anticancer drugs, we have searched for potential sources of selective anticancer drugs in a variety of plants. After collecting 45 plants and preparing 65 extracts, we used a cancer cell line and a normal cell line from the same tissue to detect selective cytotoxic activity [2-4]. Several extracts induced selective cytotoxicity towards the cancer cell line, including extracts from Cascabela thevetia (L.) Lippold (Apocynaceae), Frangula alnus Mill. (Rhamnaceae), Iberis ciliata subsp. contracta (Pers.) Moreno (Brassicaceae), Juniperus macrocarpa Sm (Cupressaceae), Pancratium maritimum L. (Amaryllidaceae), and Tetraclinis articulata (Vahl) Mast. (Cupressaceae). Due to the fact that the selective anticancer activity of Tetraclinis articulata (Vahl) Mast was high, we evaluated and observed cytotoxic activity in an additional 22 cancer cell lines, representing the most common types of cancer. Our study shows that several plants are promising sources for the isolation and the development of new anticancer drugs with cancer-selective toxicity.

\section{Materials and Methods}

\subsection{Plant Material}

All plants were collected by F. García between November 2012 and April 2013 in several areas of Sevilla, Cadiz, and Huelva (Andalusia, Spain). Collection was non-destructive and plant specimens (5-110 g) were carefully selected to avoid any damage that could affect the conservation of any species. A voucher specimen was deposited in the herbarium at the CITIUS II Celestino Mutis (Center for Research, Technology, and Innovation of the University of Seville). The botanical names, plant parts, and voucher specimen numbers are listed in Table 1. Collection coordinates are provided in Table 4. 
Table 4. Collection coordinates of plants used in this work.

\begin{tabular}{|c|c|c|}
\hline Extract & Plant Name & Collection Coordinates \\
\hline 1 & Acis autumnalis (L.) Sweet & $37^{\circ} 14^{\prime} 22.06^{\prime \prime} \mathrm{N} 6^{\circ} 11^{\prime} 37.85^{\prime \prime} \mathrm{W}$ \\
\hline $2-3$ & Anagallis monelli $\mathrm{L}$. & $36^{\circ} 36^{\prime} 15.24^{\prime \prime} \mathrm{N} 6^{\circ} 16^{\prime} 2.76^{\prime \prime} \mathrm{W}$ \\
\hline 4 & Anthyllis hamosa Desf. & $37^{\circ} 04^{\prime} 25.2^{\prime \prime} \mathrm{N} 6^{\circ} 41^{\prime} 19.68^{\prime \prime} \mathrm{W}$ \\
\hline $5-6$ & Aristolochia baetica L. & $37^{\circ} 14^{\prime} 16.68^{\prime \prime} \mathrm{N} 6^{\circ} 11^{\prime} 48.38^{\prime \prime} \mathrm{W}$ \\
\hline 7 & Armeria pungens (Link) Hoffmanns. \& Link & $37^{\circ} 04^{\prime} 13.73^{\prime \prime} \mathrm{N} 6^{\circ} 41^{\prime} 16.97^{\prime \prime} \mathrm{W}$ \\
\hline 8 & Armeria velutina Welw. ex Boiss. \& Reut. & $37^{\circ} 02^{\prime} 33.33^{\prime \prime} \mathrm{N} 6^{\circ} 35^{\prime} 53.85^{\prime \prime} \mathrm{W}$ \\
\hline 9 & Campanula lusitanica L. & $37^{\circ} 14^{\prime} 14.46^{\prime \prime} \mathrm{N} 6^{\circ} 11^{\prime} 55.8^{\prime \prime} \mathrm{W}$ \\
\hline 10 & Cascabela thevetia (L.) Lippold & $37^{\circ} 22^{\prime} 59.8^{\prime \prime} \mathrm{N} 5^{\circ} 59^{\prime} 27.36^{\prime \prime} \mathrm{W}$ \\
\hline 11-13 & Centaurea sphaerocephala L. & $37^{\circ} 05^{\prime} 40.18^{\prime \prime} \mathrm{N} 6^{\circ} 43^{\prime} 37.9^{\prime \prime} \mathrm{W}$ \\
\hline 14-15 & Cistus crispus L. & $37^{\circ} 14^{\prime} 22.06^{\prime \prime} \mathrm{N} 6^{\circ} 11^{\prime} 37.85^{\prime \prime} \mathrm{W}$ \\
\hline 16 & Cistus salvifolius L. & $37^{\circ} 14^{\prime} 19.74^{\prime \prime} \mathrm{N} 6^{\circ} 11^{\prime} 40.71^{\prime \prime} \mathrm{W}$ \\
\hline 17 & Cleome violacea $\mathrm{L}$. & $37^{\circ} 14^{\prime} 23.37^{\prime \prime} \mathrm{N} 6^{\circ} 11^{\prime} 52.72^{\prime \prime} \mathrm{W}$ \\
\hline 18 & Digitalis purpurea L. & $37^{\circ} 27^{\prime} 30.78^{\prime \prime} \mathrm{N} 6^{\circ} 41^{\prime} 20.3^{\prime \prime} \mathrm{W}$ \\
\hline 19-20 & Dorycnium rectum (L.) Ser. & $37^{\circ} 20^{\prime} 14.71^{\prime \prime} \mathrm{N} 5^{\circ} 51^{\prime} 27.13^{\prime \prime} \mathrm{W}$ \\
\hline 21 & Echium gaditanum Boiss. & $37^{\circ} 04^{\prime} 11.69^{\prime \prime} \mathrm{N} 6^{\circ} 41^{\prime} 17.16^{\prime \prime} \mathrm{W}$ \\
\hline $22-23$ & Elaeoselinum foetidum (L.) Boiss. & $37^{\circ} 14^{\prime} 15.72^{\prime \prime} \mathrm{N} 6^{\circ} 11^{\prime} 50.86^{\prime \prime} \mathrm{W}$ \\
\hline $24-25$ & Erica arborea $\mathrm{L}$. & $37^{\circ} 14^{\prime} 38.35^{\prime \prime} \mathrm{N} 6^{\circ} 11^{\prime} 49.92^{\prime \prime} \mathrm{W}$ \\
\hline 26 & Erophaca baetica (L.) Boiss. & $37^{\circ} 14^{\prime} 17.72^{\prime \prime} \mathrm{N} 6^{\circ} 11^{\prime} 46.41^{\prime \prime} \mathrm{W}$ \\
\hline $27-28$ & Frangula alnus Mill. & $37^{\circ} 05^{\prime} 40.46^{\prime \prime} \mathrm{N} 6^{\circ} 43^{\prime} 34.47^{\prime \prime} \mathrm{W}$ \\
\hline 29 & Genista hirsuta M. Vahl & $37^{\circ} 14^{\prime} 16.70$ “N $6^{\circ} 11^{\prime} 49.05^{\prime \prime} \mathrm{W}$ \\
\hline $30-31$ & Halimium calycinum (L.) K. Koch & $37^{\circ} 14^{\prime} 21.27 \mathrm{~N} 6^{\circ} 11^{\prime} 38.12^{\prime \prime} \mathrm{W}$ \\
\hline $32-33$ & Halimium halimifolium (L.) Willk. & $37^{\circ} 14^{\prime} 23.43^{\prime \prime} \mathrm{N} 6^{\circ} 11^{\prime} 38.77^{\prime \prime} \mathrm{W}$ \\
\hline $34-36$ & Hedysarum coronarium $\mathrm{L}$. & $36^{\circ} 36^{\prime} 39.92^{\prime \prime} \mathrm{N} 6^{\circ} 16^{\prime} 46.6^{\prime \prime} \mathrm{W}$ \\
\hline 37 & Iberis ciliata subsp. contracta (Pers.) Moreno & $37^{\circ} 04^{\prime} 47.25^{\prime \prime} \mathrm{N} 6^{\circ} 41^{\prime} 13.82^{\prime \prime} \mathrm{W}$ \\
\hline 38 & Jasione montana L. & $37^{\circ} 13^{\prime} 45.76^{\prime \prime} \mathrm{N} 6^{\circ} 9^{\prime} 16.08^{\prime \prime} \mathrm{W}$ \\
\hline $39-40$ & Juniperus macrocarpa $\mathrm{Sm}$. & $37^{\circ} 04^{\prime} 13.53^{\prime \prime} \mathrm{N} 6^{\circ} 41^{\prime} 16.34^{\prime \prime} \mathrm{W}$ \\
\hline 41 & Malcolmia lacera (L.) DC. & $37^{\circ} 13^{\prime} 45.76^{\prime \prime} \mathrm{N} 6^{\circ} 9^{\prime} 16.08^{\prime \prime} \mathrm{W}$ \\
\hline 42 & Malva hispanica L. & $37^{\circ} 14^{\prime} 16.09^{\prime \prime} \mathrm{N} 6^{\circ} 11^{\prime} 51.89^{\prime \prime} \mathrm{W}$ \\
\hline 43 & Ononis subspicata Lag. & $37^{\circ} 04^{\prime} 45.90^{\prime \prime} \mathrm{N} 6^{\circ} 41^{\prime} 14.14^{\prime \prime} \mathrm{W}$ \\
\hline 44 & Ornithopus compressus L. & $37^{\circ} 13^{\prime} 45.76^{\prime \prime} \mathrm{N} 6^{\circ} 9^{\prime} 16.08^{\prime \prime} \mathrm{W}$ \\
\hline 45 & Ornithopus sativus Brot. & $37^{\circ} 13^{\prime} 45.76^{\prime \prime} \mathrm{N} 6^{\circ} 9^{\prime} 16.08^{\prime \prime} \mathrm{W}$ \\
\hline 46 & Pancratium maritimum $\mathrm{L}$. & $37^{\circ} 04^{\prime} 11.14^{\prime \prime} \mathrm{N} 6^{\circ} 41^{\prime} 16.29^{\prime \prime} \mathrm{W}$ \\
\hline $47-48$ & Pycnocomon rutifolium (Vahl) Hoffmanns. \& Link & $36^{\circ} 36^{\prime} 12.69^{\prime \prime} \mathrm{N} 6^{\circ} 15^{\prime} 54.45^{\prime \prime} \mathrm{W}$ \\
\hline 49 & Ranunculus peltatus Schrank & $37^{\circ} 13^{\prime} 45.76^{\prime \prime} \mathrm{N} 6^{\circ} 9^{\prime} 16.08^{\prime \prime} \mathrm{W}$ \\
\hline $50-52$ & $\begin{array}{c}\text { Rhamnus lycioides subsp. oleoides (L.) Jahand. \& } \\
\text { Maire }\end{array}$ & $37^{\circ} 14^{\prime} 25.18^{\prime \prime} \mathrm{N} 6^{\circ} 11^{\prime} 38.35^{\prime \prime} \mathrm{W}$ \\
\hline 53 & Scrophularia frutescens L. & $37^{\circ} 04^{\prime} 47.25^{\prime \prime} \mathrm{N} 6^{\circ} 41^{\prime} 13.82^{\prime \prime} \mathrm{W}$ \\
\hline 54 & Stauracanthus genistoides (Brot.) G. Sampaio & $37^{\circ} 04^{\prime} 44.55^{\prime \prime} \mathrm{N} 6^{\circ} 41^{\prime} 16.05^{\prime \prime} \mathrm{W}$ \\
\hline $55-56$ & Tamarix canariensis Willd. & $37^{\circ} 15^{\prime} 45.64^{\prime \prime} \mathrm{N} 5^{\circ} 59^{\prime} 50.9^{\prime \prime} \mathrm{W}$ \\
\hline 57 & Taxus baccata $\mathrm{L}$. & $37^{\circ} 22^{\prime} 27^{\prime \prime} \mathrm{N} 5^{\circ} 59^{\prime} 19^{\prime \prime} \mathrm{W}$ \\
\hline 58 & Tetraclinis articulata (Vahl) Mast. & $37^{\circ} 22^{\prime} 22.18^{\prime \prime} \mathrm{N} 5^{\circ} 59^{\prime} 10.75^{\prime \prime} \mathrm{W}$ \\
\hline 59 & Teucrium fruticans $\mathrm{L}$. & $37^{\circ} 14^{\prime} 42.60^{\prime \prime} \mathrm{N} 6^{\circ} 11^{\prime} 52.78^{\prime \prime} \mathrm{W}$ \\
\hline 60 & Thymus mastichina (L.) L. & $37^{\circ} 02^{\prime} 33.33^{\prime \prime} \mathrm{N} 6^{\circ} 35^{\prime} 53.85^{\prime \prime} \mathrm{W}$ \\
\hline 61 & Tolpis barbata (L.) Gaertn. & $37^{\circ} 13^{\prime} 45.76^{\prime \prime} \mathrm{N} 6^{\circ} 9^{\prime} 16.08^{\prime \prime} \mathrm{W}$ \\
\hline $62-63$ & Ulex parviflorus Pourr. subsp. parviflorus & $37^{\circ} 13^{\prime} 48.06^{\prime \prime} \mathrm{N} 6^{\circ} 1^{\prime} 31.4^{\prime \prime} \mathrm{W}$ \\
\hline $64-65$ & Viburnum tinus L. & $37^{\circ} 22^{\prime} 27^{\prime \prime} \mathrm{N} 5^{\circ} 59^{\prime} 19^{\prime \prime} \mathrm{W}$ \\
\hline
\end{tabular}

\subsection{Preparation of the Extracts}

Extracts were prepared within several hours after collecting the plants. Fresh plant material (5-110 g) was extracted with 100-200 mL of ethanol/ethyl acetate/water (1:1:1) at $60{ }^{\circ} \mathrm{C}$ for $1 \mathrm{~h}$ by using an ultrasound water bath apparatus. After vacuum filtration, ethanol and ethyl acetate were eliminated in a rotary vacuum evaporator at $60{ }^{\circ} \mathrm{C}$. Finally, the remaining water solution was lyophilized to yield dried extracts. The extraction yield (\%) for each extract (see identification number in Table 1) was: 1 (1.9\%), 2 (3.0\%), 3 (5.6\%), $4(4.5 \%), 5(0.9 \%), 6(2.9 \%), 7(5.9 \%), 8(4.0 \%), 9(2.7 \%), 10(5.5 \%), 11(2.0 \%), 12(2.9 \%), 13$ (3.5\%), $14(8.5 \%), 15(5.2 \%), 16(7.4 \%), 17(8.9 \%), 18(\mathrm{Nd}), 19(6.7 \%), 20(7.2 \%), 21(2.4 \%), 22$ (1.9\%), 23 (2.4\%), 24 (6.0\%), 25 (14.8\%), 26 (3.3\%), $27(1.0 \%), 28(4.4 \%), 29(6.8 \%), 30(10.6 \%)$, 
$31(4.9 \%), 32(9.6 \%), 33(4.6 \%), 34(4.2 \%), 35(4.0 \%), 36(3.3 \%), 37(4.2 \%), 38(3.2 \%), 39(5.9 \%)$, $40(7.5 \%), 41(5.3 \%), 42(3.4 \%), 43(2.7 \%), 44(3.5 \%), 45(2.4 \%), 46(3.7 \%), 47(2.6 \%), 48(5.5 \%)$, $49(0.9 \%), 50(4.4 \%), 51(5.5 \%), 52(4.3 \%), 53(5.8 \%), 54(5.9 \%), 55(\mathrm{Nd}), 56(8.4 \%), 57(7.8 \%)$, $58(5.5 \%), 59(8.1 \%), 60(6.5 \%), 61(3.6 \%), 62(10.7 \%), 63(6.6 \%), 64(9.0 \%)$, and $65(9.9 \%)$. The extracts were stored in dark glass bottles and kept in a cool dark place. The first cytotoxicity experiment of the screening was carried out within the first month after preparing the extracts to avoid the possible degradation of active compounds. In the first cytotoxicity experiment, a stock solution of each extract was prepared in DMSO $(100 \mathrm{mg} / \mathrm{mL})$; a part of this solution was diluted in culture medium and immediately used to treat the cells. The stock solutions were aliquoted and frozen at $-80^{\circ} \mathrm{C}$. The rest of independent cytotoxicity experiments were carried out using different aliquots to avoid freeze-thaw cycles.

\subsection{Chemicals and Cell Lines}

Cisplatin, MTT (3-(4,5-dimethylthiazol-2-yl)-2,5-diphenyltetrazolium bromide), and resazurin were bought from Sigma. MRC-5 (human fetal lung fibroblastic cells) and A549 (human non-small-cell lung cancer cells) were purchased from the European Collection of Cell Cultures. MDA-MB-231 (human triple-negative breast cancer cells) was purchased from the American Type Culture Collection (ATCC). UACC-62 (human BRAF mutant melanoma cells) was obtained from National Cancer Institute. HepG2 (human hepatocellular carcinoma cells), PC3 (human prostate cancer cells), HT29 (human colorectal cancer cells), MCF7 (human breast cancer cells), HeLa (human cervical carcinoma cells), NB4 (human acute promyelocytic leukemia cells), HL-60 (human acute promyelocytic leukemia cells), SW480 (human colon adenocarcinoma cells), and U2OS (human osteosarcoma cells) were kindly provided by Dr. Helleday (Karolinska Institute, Sweden). HNO97 (human tongue cancer cells), A64-CLS (human submaxillary gland adenoma cells), AN3Ca (human endometrial adenocarcinoma cells), Sk-OV-3 (human ovarian cancer cells), KATO III (human gastric cancer cells), Sk-Br-3 (HER2-positive breast cancer cells), T24 (human bladder cancer cells), Calu-1 (human squamous lung cancer cells), and MeWo (human BRAF wild-type melanoma cells) were purchased from Cell Lines Service (CLS). GAMG cells (human glioblastoma cells) were provided by Dr. A. Ayala (University of Seville). BJ-hTERT (hTERT-immortalized foreskin fibroblast BJ cells), BJ-SV40T (SV40T-transformed BJ-hTERT cells), and BJ RASV12 (H-RAS V12-transformed BJ-SV40T cells) were provided by Dr. Hahn (Dana-Farber Cancer Institute, USA) [14]. Cells were maintained in appropriate medium and propagated according to standard protocols. MRC-5, A549, MDA-MB-231, HepG2, HT29, MCF7, HeLa, SW48, U2OS, HNO97, A64-CLS, AN3Ca, SK-OV-3, Sk-Br-3, MeWo, GAMG, BJ-hTERT, BJ-SV40T, and BJ-RASV12, were maintained in Dulbecco's modified Eagle's medium (DMEM) high-glucose medium. PC3 and T24 were grown in DMEMF12. UACC-62, NB4, HL60, and Calu-1 were maintained in RPMI 1640. KATO III were grown in Ham's F12. All media were supplemented with $100 \mathrm{U} / \mathrm{mL}$ penicillin, $100 \mu \mathrm{g} / \mathrm{mL}$ streptomycin, and $10 \%$ fetal bovine serum. All cells were kept at $37{ }^{\circ} \mathrm{C}$ in a humidified atmosphere containing $5 \% \mathrm{CO}_{2}$. Cell culture reagents were purchased from Biowest.

\subsection{Cell Viability Assays}

Exponentially growing cells (3000-5000 cells per well) were seeded in 96-well plates and were allowed to grow for $24 \mathrm{~h}$. The cells were then exposed to several concentrations of the extracts or the positive controls cisplatin and 5-fluorouracil. After a treatment period of $72 \mathrm{~h}$, cell viability was estimated with the MTT assay or the resazurin assay [2,15]. Due to the fact that plant extracts contain compounds (e.g., polyphenols) that may interfere with these assays, cell culture medium was removed before conducting these assays in all adherent cell lines.

The MTT assay is based on the ability of viable cells to convert the MTT compound (3(4,5-dimethylthiazol-2-yl)-2,5-diphenyltetrazolium bromide) into an insoluble and purple formazan product. After an incubation period of the cells with the MTT and a solubilization step, the quantity of the colored product was measured with a plate reading spectropho- 
tometer. Dead cells are metabolically inactive and cannot produce the colored product. Briefly, after the $72 \mathrm{~h}$ treatment period, the medium was removed, the cells were washed with PBS, and $125 \mu \mathrm{L}$ MTT ( $1 \mathrm{mg} / \mathrm{mL}$ in medium) was added to each well. The plates were incubated for $4 \mathrm{~h}$ to allow viable cells to transform the MTT compound into an insoluble formazan product. This insoluble compound was solubilized by adding $80 \mu \mathrm{L}$ $20 \%$ SDS in $0.02 \mathrm{M} \mathrm{HCl}$ to each well and by incubating the plates overnight at $37^{\circ} \mathrm{C}$. Finally, optical densities were measured at $540 \mathrm{~nm}$ on a multi-well plate spectrophotometer reader (Multiskan EX Labsystems, Vantaa, Finland).

The resazurin assay is a redox-based colorimetric or fluorometric assay based on the capacity of viable cells to reduce the blue compound resazurin into the pink, fluorescent and soluble product resorufin. The quantity of resorufin produced is proportional to the number of viable cells. After treatment period, medium was removed and $150 \mu \mathrm{L}$ of resazurin $(20 \mu \mathrm{g} / \mathrm{mL}$ in medium $)$ was added to each well for 5-6 h. The absorbance was measured at $540 \mathrm{~nm}$ and $620 \mathrm{~nm}$ on a multi-well plate spectrophotometer reader (Multiskan EX Labsystems, Vantaa, Finland).

In both assays, cell viability was calculated as a percentage in relation to untreated cells from at least two independent experiments. IC50 values were calculated by linear regression analysis after selecting the two concentrations leading to cell viability values immediately above and below $50 \%$. With this approach, IC50 values always are within the experimentally observed concentration range [15,34-37]. After estimating cell viability and calculating IC50 values, results were expressed as mean \pm standard error of the mean (SEM), and a t-test (paired, two tailed) was used for statistical analysis. A $p$-value $>0.05$ was not considered statistically significant and was not represented by any symbol. A $p$-value $\leq 0.05$ was considered statistically significant and was represented with an asterisk, two asterisks $(p \leq 0.01)$, or three asterisks $(p \leq 0.001)$. Since selectivity is the most relevant parameter to detect anticancer potential in vitro [3,4], selectivity indices were used to quantify this parameter. The selectivity index (S.I.) was calculated as the average of the IC50 value in the normal cell line (MRC-5) divided by the IC50 value in the cancer cell line (A549) obtained in each independent experiment [3].

Supplementary Materials: The following are available online at https:/ /www.mdpi.com/article/10 $.3390 /$ plants10102193/s1. Figure S1: Comparison of cytotoxicity of Tetraclinis articulata (Vahl) Mast. extract (58) assessed by MTT and resazurin assays. A549 and MRC-5 cells were treated for $72 \mathrm{~h}$. Figure S2: Tetraclinis articulata (Vahl) Mast. (Cupressaceae). General view of the plant (a) and the plant material (b) used in the present study.

Author Contributions: Conceptualization, J.M.C.-M. and M.L.-L.; data curation, F.G., A.A. and M.L.-L.; formal analysis, E.G.-M. and J.J.J.-A.; investigation, J.M.C.-M., S.M.M.-S., V.J.-G. and J.J.J.-A.; methodology, S.M.M.-S., V.J.-G. and E.G.-M.; supervision, F.G., A.A. and M.L.-L.; validation, E.B.-M. and P.D.-O.; writing-original draft, M.L.-L.; writing—review and editing, J.M.C.-M., V.J.-G. and E.B.-M. All authors have read and agreed to the published version of the manuscript.

Funding: This research was partially funded by the University of Seville (grant numbers VPPI-I.5).

Institutional Review Board Statement: Not applicable.

Informed Consent Statement: Not applicable.

Data Availability Statement: Not applicable.

Acknowledgments: Authors would like to thank to the biology and herbarium services of CITIUSUniversity of Seville for maintaining the cell lines and preserving the vouchers of the plants. They are especially grateful for the financial support from V Plan Propio (University of Seville). The graphical abstract was created with BioRender.

Conflicts of Interest: The authors declare no conflict of interest. 


\section{References}

1. Siegel, R.L.; Miller, K.D.; Fuchs, H.E.; Jemal, A. Cancer Statistics, 2021. CA Cancer J. Clin. 2021, 71, 7-33. [CrossRef]

2. López-Lázaro, M. A simple and reliable approach for assessing anticancer activity in vitro. Curr. Med. Chem. 2015, 22, 1324-1334. [CrossRef] [PubMed]

3. López-Lázaro, M. Two preclinical tests to evaluate anticancer activity and to help validate drug candidates for clinical trials. Oncoscience 2015, 2, 91-98. [CrossRef] [PubMed]

4. López-Lázaro, M. How many times should we screen a chemical library to discover an anticancer drug? Drug Discov. Today 2015, 20, 167-169. [CrossRef] [PubMed]

5. Cragg, G.M.; Grothaus, P.G.; Newman, D.J. Impact of natural products on developing new anti-cancer agents. Chem. Rev. 2009, 109, 3012-3043. [CrossRef]

6. Newman, D.J.; Cragg, G.M. Natural Products as Sources of New Drugs over the Nearly Four Decades from 01/1981 to 09/2019. J. Nat. Prod. 2020, 83, 770-803. [CrossRef]

7. Kingston, D.G.I.; Newman, D.J. The search for novel drug leads for predominately antitumor therapies by utilizing mother nature's pharmacophoric libraries. Curr. Opin. Drug Discov. Devel. 2005, 8, 207-227. [PubMed]

8. Wani, M.C.; Taylor, H.L.; Wall, M.E.; Coggon, P.; Mcphail, A.T. Plant Antitumor Agents.VI.The Isolation and Structure of Taxol, a Novel Antileukemic and Antitumor Agent from Taxus brevifolia. J. Am. Chem. Soc. 1971, 54, 2347-2360.

9. Ruiz-Ceja, K.A.; Chirino, Y.I. Current FDA-approved treatments for non-small cell lung cancer and potential biomarkers for its detection. Biomed. Pharmacother. 2017, 90, 24-37. [CrossRef]

10. Calderón-Montaño, J.M.; Martínez-Sánchez, S.M.; Burgos-Morón, E.; Guillén-Mancina, E.; Jiménez-Alonso, J.J.; García, F.; Aparicio, A.; López-Lázaro, M. Screening for selective anticancer activity of plants from Grazalema Natural Park, Spain. Nat. Prod. Res. 2019, 33, 3454-3458. [CrossRef]

11. Valderrama, J.A.; Delgado, V.; Sepúlveda, S.; Benites, J.; Theoduloz, C.; Buc Calderon, P.; Muccioli, G.G. Synthesis and Cytotoxic Activity on Human Cancer Cells of Novel Isoquinolinequinone-Amino Acid Derivatives. Molecules 2016, 21, 1199. [CrossRef] [PubMed]

12. Motadi, L.R.; Choene, M.S.; Mthembu, N.N. Anticancer Properties of Tulbaghia Violacea Regulate the Expression of P53Dependent Mechanisms in Cancer Cell Lines. Sci. Rep. 2020, 10, 1-11. [CrossRef] [PubMed]

13. Gao, J.; Luo, T.; Wang, J. Gene Interfered-Ferroptosis Therapy for Cancers. Nat. Commun. 2021, 12, 1-16. [CrossRef]

14. Hahn, W.C.; Counter, C.M.; Lundberg, A.S.; Beijersbergen, R.L.; Brooks, M.W.; Weinberg, R.A. Creation of human tumour cells with defined genetic elements. Nature 1999, 400, 464-468. [CrossRef]

15. Calderón-Montaño, J.M.; Burgos-Morón, E.; Orta, M.L.; Mateos, S.; López-Lázaro, M. A hydroalcoholic extract from the leaves of Nerium oleander inhibits glycolysis and induces selective killing of lung cancer cells. Planta Med. 2013, 79, 1017-1023. [CrossRef] [PubMed]

16. López-Lázaro, M.; Palma De La Peña, N.; Pastor, N.; Martín-Cordero, C.; Navarro, E.; Cortés, F.; Ayuso, M.J.; Toro, M.V. Anti-tumour activity of Digitalis purpurea L. subsp. heywoodii. Planta Med. 2003, 69, 701-704. [PubMed]

17. López-Lázaro, M.; Pastor, N.; Azrak, S.S.; Ayuso, M.J.; Austin, C.A.; Cortés, F. Digitoxin inhibits the growth of cancer cell lines at concentrations commonly found in cardiac patients. J. Nat. Prod. 2005, 68, 1642-1645. [CrossRef]

18. López-Lázaro, M. Digitoxin as an anticancer agent with selectivity for cancer cells: Possible mechanisms involved. Expert Opin. Ther. Targets 2007, 11, 1043-1053. [CrossRef]

19. Calderón-Montaño, J.M.; Burgos-Morón, E.; Orta, M.L.; Maldonado-Navas, D.; García-Domínguez, I.; López-Lázaro, M. Evaluating the cancer therapeutic potential of cardiac glycosides. Biomed. Res. Int. 2014, 2014, 794930. [CrossRef]

20. Ramos-Silva, A.; Tavares-Carreón, F.; Figueroa, M.; De la Torre-Zavala, S.; Gastelum-Arellanez, A.; Rodríguez-García, A.; GalánWong, L.J.; Avilés-Arnaut, H. Anticancer potential of Thevetia peruviana fruit methanolic extract. BMC Complement. Altern. Med. 2017, 17, 241. [CrossRef]

21. Calderón-Montaño, J.M.; Burgos-Morón, E.; López-Lázaro, M. The in vivo antitumor activity of cardiac glycosides in mice xenografted with human cancer cells is probably an experimental artifact. Oncogene 2014, 33, 2947-2948. [CrossRef] [PubMed]

22. Fujino, T.; Kuroda, M.; Matsuo, Y.; Kubo, S.; Tamura, C.; Sakamoto, N.; Mimaki, Y.; Hayakawa, M. Cardenolide glycosides from the seeds of Digitalis purpurea exhibit carcinoma-specific cytotoxicity toward renal adenocarcinoma and hepatocellular carcinoma cells. Biosci. Biotechnol. Biochem. 2015, 79, 177-184. [CrossRef] [PubMed]

23. Zhu, J.-J.; Zhang, X.-X.; Miao, Y.-Q.; He, S.-F.; Tian, D.-M.; Yao, X.-S.; Tang, J.-S.; Gan, Y. Delivery of acetylthevetin B, an antitumor cardiac glycoside, using polymeric micelles for enhanced therapeutic efficacy against lung cancer cells. Acta Pharmacol. Sin. 2017, 38, 290-300. [CrossRef] [PubMed]

24. Youssef, D.T.; Frahm, A.W. Alkaloids of the flowers of Pancratium maritimum. Planta Med. 1998, 64, 669-670. [CrossRef] [PubMed]

25. Ibrahim, S.; Mohamed, G.; Shaala, L.; Youssef, D.; El Sayed, K. New Alkaloids from Pancratium maritimum. Planta Med. 2013, 79, 1480-1484. [CrossRef]

26. Witherup, K.M.; Look, S.A.; Stasko, M.W.; Ghiorzi, T.J.; Muschik, G.M.; Cragg, G.M. Taxus spp. needles contain amounts of taxol comparable to the bark of Taxus brevifolia: Analysis and isolation. J. Nat. Prod. 1990, 53, 1249-1255. [CrossRef] [PubMed]

27. Duquesnoy, E.; Paoli, M.; Castola, V.; Bighelli, A.; Casanova, J. Identification of taxanes in extracts from leaves of Taxus baccata L. using (13)C-NMR spectroscopy. Phytochem. Anal. 2009, 20, 246-252. [CrossRef] 
28. Azémard, C.; Ménager, M.; Vieillescazes, C. On the tracks of sandarac, review and chemical analysis. Environ. Sci. Pollut. Res. 2017, 24, 27746-27754. [CrossRef]

29. Jlizi, S.; Lahmar, A.; Zardi-Bergaoui, A.; Ascrizzi, R.; Flamini, G.; Harrath, A.H.; Chekir-Ghedira, L.; Ben Jannet, H. Chemical Composition and Cytotoxic Activity of the Fractionated Trunk Bark Essential Oil from Tetraclinis articulata (Vahl) Mast. Growing in Tunisia. Molecules 2021, 26, 1110. [CrossRef]

30. El Jemli, M.; Kamal, R.; Marmouzi, I.; Doukkali, Z.; Bouidida, E.H.; Touati, D.; Nejjari, R.; El Guessabi, L.; Cherrah, Y.; Alaoui, K. Chemical composition, acute toxicity, antioxidant and anti-inflammatory activities of Moroccan Tetraclinis articulata L. J. Tradit. Complement. Med. 2017, 7, 281-287. [CrossRef]

31. Ho, S.T.; Tung, Y.T.; Kuo, Y.H.; Lin, C.C.; Wu, J.H. Ferruginol inhibits non-small cell lung cancer growth by inducing caspaseassociated apoptosis. Integr. Cancer Ther. 2015, 14, 86-97. [CrossRef]

32. Yu, X.; Lin, H.; Wang, Y.; Lv, W.; Zhang, S.; Qian, Y.; Deng, X.; Feng, N.; Yu, H.; Qian, B. D-limonene exhibits antitumor activity by inducing autophagy and apoptosis in lung cancer. Onco Targets Ther. 2018, 11, 1833-1847. [CrossRef]

33. Chung, K.S.; Hong, J.Y.; Lee, J.H.; Lee, H.J.; Park, J.Y.; Choi, J.H.; Park, H.J.; Hong, J.; Lee, K.T. B-Caryophyllene in the essential oil from chrysanthemum boreale induces G1 phase cell cycle arrest in human lung cancer cells. Molecules 2019, 24, 3754. [CrossRef] [PubMed]

34. Sirakanyan, S.N.; Spinelli, D.; Geronikaki, A.; Hakobyan, E.K.; Sahakyan, H.; Arabyan, E.; Zakaryan, H.; Nersesyan, L.E.; Aharonyan, A.S.; Danielyan, I.S.; et al. Synthesis, Antitumor Activity, and Docking Analysis of New Pyrido [3,2:4,5] furo (thieno)[3,2-d]pyrimidin-8-amines. Molecules 2019, 24, 3952. [CrossRef] [PubMed]

35. Zhao, J.; Li, Q.Q.; Zou, B.; Wang, G.; Li, X.; Kim, J.E.; Cuff, C.F.; Huang, L.; Reed, E.; Gardner, K. In vitro combination characterization of the new anticancer plant drug $\beta$-elemene with taxanes against human lung carcinoma. Int. J. Oncol. 2007, 31, 241-252. [CrossRef] [PubMed]

36. Kaczirek, K.; Schindl, M.; Weinhäusel, A.; Scheuba, C.; Passler, C.; Prager, G.; Raderer, M.; Hamilton, G.; Mittlböck, M.; Siegl, V.; et al. Cytotoxic Activity of Camptothecin and Paclitaxel in Newly Established Continuous Human Medullary Thyroid Carcinoma Cell Lines. J. Clin. Endocrinol. Metab. 2004, 89, 2397-2401. [CrossRef]

37. Martín-Banderas, L.; Muñoz-Rubio, I.; Prados, J.; Álvarez-Fuentes, J.; Calderón-Montaño, J.M.; López-Lázaro, M.; Arias, J.L.; Leiva, M.C.; Holgado, M.A.; Fernández-Arévalo, M. In vitro and in vivo evaluation of Delta (9)-tetrahidrocannabinol/PLGA nanoparticles for cancer chemotherapy. Int. J. Pharm. 2015, 487, 205-212. [CrossRef] [PubMed] 